\title{
Distribution and degradation of terrestrial organic matter in the sediments of peat-draining rivers, Sarawak, Malaysian Borneo
}

\author{
Ying Wu ${ }^{1}$, Kun Zhu ${ }^{1}$, Jing Zhang ${ }^{1}$, Moritz Müller ${ }^{2}$, Shan Jiang ${ }^{1}$, Aazani Mujahid ${ }^{3}$, Mohd Fakharuddin Muhamad ${ }^{3}$, \\ and Edwin Sien Aun Sia ${ }^{2}$ \\ ${ }^{1}$ State Key Laboratory of Estuary and Coastal Research, East China Normal University, Shanghai, China \\ ${ }^{2}$ Faculty of Engineering, Computing and Science, Swinburne University of Technology, Sarawak campus, Kuching, Malaysia \\ ${ }^{3}$ Department of Aquatic Science, Faculty of Resource Science and Technology, University Malaysia Sarawak, \\ Sarawak, Malaysia
}

Correspondence: Ying Wu (wuying@sklec.ecnu.edu.cn)

Received: 14 March 2019 - Discussion started: 10 April 2019

Revised: 10 October 2019 - Accepted: 23 October 2019 - Published: 28 November 2019

\begin{abstract}
Tropical peatlands are one of the largest pools of terrestrial organic carbon $\left(\mathrm{OC}_{\text {terr }}\right)$; however, our understanding of the dynamics of $\mathrm{OC}_{\text {terr }}$ in peat-draining rivers remains limited, especially in Southeast Asia. This study used bulk parameters and lignin phenol concentrations to investigate the characteristics of $\mathrm{OC}_{\text {terr }}$ in a tropical peat-draining river system (the main channel of the Rajang and three smaller rivers: the Maludam, Simunjan, and Sebuyau) in the western part of Sarawak, Malaysian Borneo. The depleted $\delta^{13} \mathrm{C}$ levels and lignin composition of the organic matter indicates that the most important plant source of the organic matter in these rivers is woody angiosperm $\mathrm{C}_{3}$ plants, especially in the three small rivers sampled. The diagenetic indicator ratio, i.e., the ratio of acid to aldehyde of vanillyl phenols $\left((\mathrm{Ad} / \mathrm{Al})_{\mathrm{V}}\right)$, increased with decreasing mean grain size of sediment from the small rivers. The selective sorption of acid relative to aldehyde phenols might explain the variations in the $(\mathrm{Ad} / \mathrm{Al})_{\mathrm{V}}$ ratio. Elevated $(\mathrm{Ad} / \mathrm{Al})_{\mathrm{V}}$ values observed from the Maludam's sediments may also be attributed to source plant variations. The $(\mathrm{Ad} / \mathrm{Al})_{\mathrm{V}}$ ratio appears to be related to the $\mathrm{C} / \mathrm{N}$ ratio (the ratio of total organic carbon to total nitrogen) in the Rajang and small rivers. In small rivers, a quick decline of $\mathrm{C} / \mathrm{N}$ ratios is a response to the slower modification of $(\mathrm{Ad} / \mathrm{Al})_{\mathrm{V}}$ ratios due to better preservation of lignin phenols. An accumulation of lignin phenols with higher total nitrogen percentages (TN\%) in the studied systems was observed. Most of the $\mathrm{OC}_{\text {terr }}$ discharged from the Rajang and small river systems was material derived from woody angiosperm plants with limited diagenetic alteration
\end{abstract}

before deposition and thus could potentially provide significant carbon to the atmosphere after degradation.

\section{Introduction}

Tropical peatlands are one of the biggest terrestrial organic carbon pools, accounting for about $89000 \mathrm{Tg}$ (Moore et al., 2013; Rieley et al., 1996, 2008). It is reported that about $77 \%$ of the carbon stored in all tropical peatlands is derived from Southeast Asia, which equals $11 \%-14 \%$ of the total carbon pool stored in all peat. However, increasing anthropogenic disturbance in the form of land-use change, drainage and biomass burning are converting this peat into a globally significant source of atmospheric carbon dioxide (Dommain et al., 2014; Miettinen et al., 2016; Koh et al., 2009; Page et al., 2011). The rivers draining these peatlands are typically rich in lignin phenols and humic substances and are often referred to as "blackwater" rivers (Baum et al., 2007; Cook et al., 2017; Moore et al., 2011). However, knowledge of the fate of terrigenous organic matter in such peat-draining rivers and estuaries remains limited (Gandois et al., 2014; Hall et al., 2015; Lourençato et al., 2019).

The transport, degradation, and sequestration of terrestrial organic carbon $\left(\mathrm{OC}_{\text {terr }}\right)$ in river systems are important because of their roles in constraining carbon cycle budgets (Aufdenkampe et al., 2011; Battin et al., 2009; Feng et al., 2016; Spencer et al., 2010; Wu et al., 2018). In terms of transport within fluvial systems, $\mathrm{OC}_{\text {terr }}$ is subject to various 
natural processes, such as photo bleaching, microbial degradation, and selective preservation, as well as anthropogenic activities, e.g, dam construction, irrigation systems, and landuse change (Bao et al., 2015; Hernes et al., 2017; Spencer et al., 2010; Wu et al., 2015, 2018). Thus, it can be difficult to distinguish $\mathrm{OC}_{\text {terr }}$ behavior from dynamics within a fluvial system. Multiple geochemical approaches have been applied to elucidate the composition and fate of $\mathrm{OC}_{\text {terr }}$ in riverine and coastal sediments, including $\mathrm{C} / \mathrm{N}$ ratios, $\delta^{13} \mathrm{C}$ composition, and the distribution and composition of specific biomarker compounds, such as lignin phenols and plant wax n-alkanes (Bao et al., 2015; Drenzek et al., 2007; Goñi et al., 2005; Hernes and Benner, 2002; Jex et al., 2014; Ward et al., 2013). Lignin, which constitutes up to $30 \%$ of vascular plant biomass, is a unique biomarker of $\mathrm{OC}_{\text {terr }}$. Although highly degraded soil organic matter may be devoid of any apparent lignin, it is another important contributor to

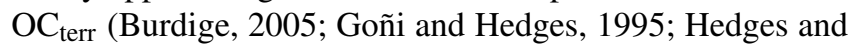
Mann, 1979). The monomeric composition of lignin phenols (S, V, C series) provides useful information about the biological source (woody versus nonwoody and angiosperm versus gymnosperm) and the oxidation stage of lignin in natural environments (Benner et al., 1984; Hedges et al., 1985; Dittmar and Lara, 2001; Tareq et al., 2004; Thevenot et al., 2010). Most studies designed to understand the sources, compositions, and transport of exported $\mathrm{OC}_{\text {terr }}$ to determine its impact on the carbon cycle have been carried out in large rivers in the temperate and polar zones (Bao et al., 2015; Bianchi et al., 2002; Bianchi and Bauer, 2011; Drenzek et al., 2007; Goñi et al., 1998, 2005; Feng et al., 2016; Wu et al., 2015, 2018). In contrast, lignin signatures from tropical environments have received less attention, especially in small river systems (Alin et al., 2008; Alkhatib et al., 2007; Dittmar and Lara, 2001; Goñi et al., 2006; Hedges et al., 1986; Spencer et al., 2010; Sun et al., 2017; Pradhan et al., 2014).

The export of $\mathrm{OC}_{\text {terr }}$ in tropical river systems is typically constrained by natural rainfall, typhoons, floods, and tectonic activity (Alin et al., 2008; Aufdenkampe et al., 2007; Bao et al., 2015). Elevated soil turnover rates, coupled with short water residence times in small tropical river catchments, lead to the accelerated transformation of terrestrial organic matter $(\mathrm{OM})$, especially during high-discharge events (Bao et al., 2015; Goldsmith et al., 2008; Kao and Liu, 1996). Anthropogenic processes such as deforestation have been proven to be a major cause of altered hydrology and OM compositions in tropical river systems (Houghton et al., 2000; Jennerjahn et al., 2004, 2008; Pradhan et al., 2014). The current paucity of information about $\mathrm{OC}_{\text {terr }}$ characteristics, and its export by rivers from tropical peat-draining rivers remains a major gap in our understanding of $\mathrm{OC}_{\text {terr }}$ biogeochemical cycling in rivers from tropical Southeast Asia. Previous studies have reported that peatland-draining rivers in Sumatra and Borneo contained the highest values of dissolved organic carbon (DOC) in rivers globally $\left(3000-5500 \mu \mathrm{mol} \mathrm{L}^{-1}\right)$ and most of the terrestrial DOC delivered into the sea (Wit et al., 2015).
To understand the biogeochemical processing of $\mathrm{OC}_{\text {terr }}$ in Southeast Asia, more work is needed on the dynamics of $\mathrm{OC}_{\text {terr }}$ in the fluvial systems of this region.

Here we present what is, to our knowledge, the first analysis of $\mathrm{OC}_{\text {terr }}$ concentration and behavior in four rivers and estuarine regions in the western part of Sarawak, Malaysian Borneo. We examined the $\mathrm{OC}_{\text {terr }}$ characteristics using the lignin phenol composition from various samples (e.g., plants, soils, and sediments) from a major river, the Rajang, and three adjacent small rivers (the Maludam, Simunjan, and Sebuyau) to resolve the sources and transformation processes in the wet season versus the dry season. We further compared data among the four rivers to determine the ultimate fate of lignin and the potential controls on its distribution. Our results also indicate that lignin composition links to sources and modifications along the river-peat and soil-estuary continuum and reveal its response to peat degradation.

\section{Materials and methods}

\subsection{Study region and sample collection}

Samples were collected during three field expeditions to Sarawak in August 2016 (only the Rajang), early March 2017 (the Rajang and the three small rivers), and September 2017 (only the small rivers; Fig. 1). During the 2017 expeditions, typical plants (Table S2 in the Supplement) and soil samples were also collected for the comparison study.

The Rajang River drainage basin covers an area of about $50000 \mathrm{~km}^{2}$. Elevations exceed $2000 \mathrm{~m}$, and hill slopes are steep, generally in excess of $258 \mathrm{~m}$ in the interior highlands and $208 \mathrm{~m}$ in lower areas (Martin et al., 2018). The three small rivers (the Maludam, Simunjan, and Sebuyau) are blackwater rivers that drain extensive peatlands (Fig. 1). The drainage basin of the Maludam is about $91.4 \mathrm{~km}^{2}$, and the majority of the river located in the Maludam National Park is covered with $10 \mathrm{~m}$ thick peat (Müller et al., 2015). The other two rivers are highly disturbed by human activity with intensive oil palm and sago plantations. For the Rajang, it is separated into two parts by Sibu Town, and its upper reaches mainly drain mineral soils, while its lower reaches develop multiple distributary channels (e.g., the lower Rajang, Serendeng, and Igan; Fig. 1). These channels are also surrounded by broad peatlands. It is reported that peat greater than $1 \mathrm{~m}$ thick covered $50 \%$ of the delta plain (Staub and Gastaldo, 2000). However, deforestation and changes in land use are accelerating the peatland degradation (Fig. 1). More than $50 \%$ of peatland ( $11 \%$ of the catchment size) in Rajang watershed has been occupied by industry plantation (e.g., oil palm) (Miettinen et al., 2016). Fishery, logging and timber processing are the traditional industries of local citizens (Miettinen et al., 2016).

The climate of the study area is classified as tropical everwet, with average rainfall in excess of $3700 \mathrm{~mm} \mathrm{yr}^{-1}$. The 


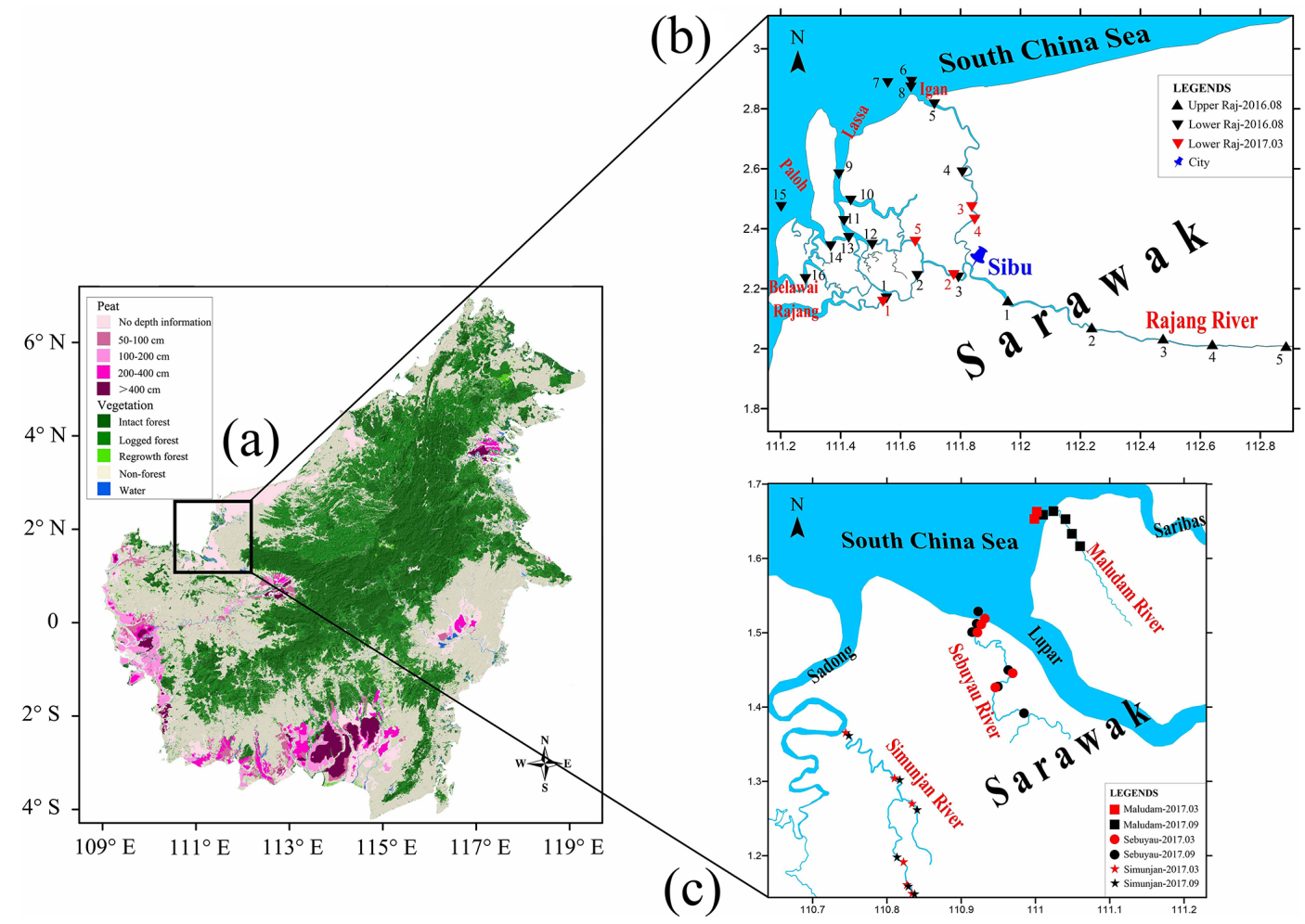

Figure 1. (a) Peat and vegetation distribution in the study region (modified from https://www.cifor.org/map/atlas/, last access: December 2018). (b) Sediment sampling sites along the Rajang and its tributaries. The city of Sibu divides the river into its upper and lower reaches. (c) Sediment sampling sites along the three small rivers. Locations of samples collected from the Maludam, Sebuyau, and Simunjan are indicated by squares, circles, and stars, respectively.

average monthly water discharge of the Rajang is about $3600 \mathrm{~m}^{3} \mathrm{~s}^{-1}$, with peak discharge $\left(\sim 25000 \mathrm{~m}^{3} \mathrm{~s}^{-1}\right)$ observed during the northeastern monsoon season (December to March; Staub and Gastaldo, 2000). However, the amount of suspended sediments delivered from the Rajang basin to the delta plain demonstrated slight variation $\left(2.0 \mathrm{Mt} \mathrm{s}^{-1}\right.$ dry season versus $2.2 \mathrm{Mt} \mathrm{s}^{-1}$ wet season) but changed substantially in the amount of sediment delivered from the delta plain to the South China Sea (Staub and Gastaldo, 2000). It is estimated that the annual sediment discharge of the Rajang is $30 \mathrm{Mt}$. The turbidity maximum in the lower Rajang channels occurred during the low or reduced discharge period. It is reported that up to $24 \mathrm{Mt}$ of sediment is deposited in the delta front, with preserved annual sediment layers on the order of $1 \mathrm{~cm}$ thick (Staub and Gastaldo, 2000). The water discharge of the Maludam is quite low, only $4.4 \pm 0.6 \mathrm{~m}^{3} \mathrm{~s}^{-1}$ from the $91.4 \mathrm{~km}^{2}$ catchment (Müller et al., 2015). The river length of Maludam is $33 \mathrm{~km}$. For the Sebuyau and Simunjan, river length is 58 and $54 \mathrm{~km}$, respectively (Martin et al., 2018). However, hydraulic information for these two rivers is largely unknown. The three sampling periods were similar to the end of the northeastern monsoon season (i.e., March, the end of the wettest season of the year) and were shortly be- fore the beginning of the northeastern monsoon season (i.e., August and September, the end of the drier season).

The surface sediments were sampled at the middle stream of river using grab samplers from a small boat at each station and then $0-5 \mathrm{~cm}$ subsamples were collected and frozen $\left(-20^{\circ} \mathrm{C}\right)$ until they were dried for subsequent analyses in the laboratory. Soil sampling was conducted at the same time along the Rajang riverbank, where the sites have minimal human disturbances and short soil cores were collected and mixed in situ as one composite sample for the depth of 0 $10 \mathrm{~cm}$ by getting rid of visible roots and detritus. The vegetation of the tropical peat swamp forest is dominated by trees, e.g., Anacardiaceae, Annonaceae, and Euphobiaceae. (Page et al., 2006). Fresh, typical vegetation (listed in Table S2) was separately collected from leaves, stems, and roots, as well as from some detritus that was floating on the surface layer of the river, for the comparison study. All botanical samples and soils within the basin were collected at the same time and stored in a freezer. The hydrological parameters of the surface river water (e.g., salinity, $\mathrm{pH}$, and temperature) at each station were determined using an Aquaread ${ }^{\circledR}$ multiple parameter probe (AP-2000). 


\subsection{Chemical analyses}

Prior to chemical analyses, all botanical samples, as well as the soil and sediment samples, were dried at $55^{\circ} \mathrm{C}$ and disaggregated in an agate mortar to form a homogeneous sample.

Grain size characteristics were measured directly from aliquots of the surface sediment samples using a Coulter LS 100Q (Coulter Company, USA) after treatment with $5 \% \mathrm{H}_{2} \mathrm{O}_{2}$ and $0.2 \mathrm{M} \mathrm{HCl}$ to dissolve organic matter and biogenic carbonate. The sediment grain sizes are expressed as the proportions of clay $(<4 \mu \mathrm{m})$, silt $(4-63 \mu \mathrm{m})$, and sand ( $>63 \mu \mathrm{m}$ ), with a measurement error of $\leq 5 \%$ for the entire dataset. The remaining sediments were ground to 80 mesh $(187.5 \mu \mathrm{m})$ for elemental, isotopic, and lignin analyses.

The concentrations of organic carbon and total nitrogen (TN) were analyzed using a CHNOS elemental analyzer (Vario EL III) with a relative precision of $\pm 5 \%$. The weight percentages of organic carbon were analyzed after removing the carbonate fraction of vapor-phase acidification. The weight percentages of $\mathrm{TN}$ were also analyzed following the same procedure but without acidification. The stable carbon isotopic composition of the decarbonated sediments was determined by a Flash EA1112 elemental analyzer connected to an isotope ratio mass spectrometer (MAT Delta Plus/XP, Finnigan). ${ }^{13} \mathrm{C} /{ }^{12} \mathrm{C}$ ratios are expressed relative to the Pee Dee Belemnite (PDB) standard using conventional $\delta$ notation. The analytical precision, determined by replicate analysis of the same sample, was $\pm 0.2 \%$.

Lignin phenols were extracted using the cupric oxide digestion technique (CuO; Hedges and Ertel, 1982; Yu et al., 2011). Briefly, the powdered samples were weighed, placed in $\mathrm{O}_{2}$-free Teflon-lined vessels, and digested in a microwave digestion system (CEM MARS5) at $150{ }^{\circ} \mathrm{C}$ for $90 \mathrm{~min}$ (Goñi and Montgomery, 2000). Samples were then acidified to $\mathrm{pH}<2$ and phenolic monomers were extracted into 99:1 (volume ratio) ethyl acetate/petroleum ether, dried, and stored at $-20^{\circ} \mathrm{C}$ until further analysis. Samples were analyzed as trimethylsilyl derivatives of N,O-Bis(trimethylsilyl)trifluoroacetamide (BSTFA) and trimethylchlorosilane (TMCS; 99:1) by Agilent $6890 \mathrm{~N}$ gas chromatography (DB-1 column, FID). The lignin phenol concentration was quantified using calibration curves based on commercial standards (Sigma Aldrich). A total of 11 phenol monomers were extracted and categorized into five groups: syringyl ( $\mathrm{S}$, syringaldehyde, acetosyringone, syringic acid), vanillyl ( $\mathrm{V}$, vanillin, acetovanillone, vanillic acid), cinnamyl $(\mathrm{C}, p$-coumaric acid, ferulic acid), p-hydroxyl ( $\mathrm{P}, p$-hydroxybenzaldehyde, $p$ hydroxyacetophenone, and $p$-hydroxybenzoic acid), and 3,5dihydroxybenzoic acid (DHBA). Coefficients of analytical variation associated with phenol values were $<10 \%$ based on replicate analysis of the same samples.

Ratios of syringyl-to-vanillyl phenols (S/V) and cinnamyl-to-vanillyl phenols $(\mathrm{C} / \mathrm{V})$ are often used to indicate the relative contribution of angiosperm and non- woody tissues versus gymnosperm wood, respectively (Hedges and Mann, 1979). Since both ratios have been found to decrease with the preferential degradation of $\mathrm{S}$ and $\mathrm{C}$ relative to $\mathrm{V}$ phenols, the lignin phenol vegetation index (LPVI) was developed to be an alternative approach to evaluate the original of various type of vegetation (Tareq et al., 2004; Thevenot et al., 2010):

$$
\begin{aligned}
& \text { Lignin phenol vegetation index }(\mathrm{LPVI})= \\
& \quad[\{\mathrm{S}(\mathrm{S}+1) /(\mathrm{V}+1)+1\} \times\{\mathrm{C}(\mathrm{C}+1) /(\mathrm{V}+1)+1\}] .
\end{aligned}
$$

The ratio of $\mathrm{P} /(\mathrm{V}+\mathrm{S})$ may reflect the diagenetic state of lignin when the other sources of $\mathrm{P}$ phenols (such as protein and tannin) are relatively constant (Dittmar and Lara, 2001). The acid-to-aldehyde (Ad/Al) ratios of $\mathrm{V}$ and $\mathrm{S}$ phenols are often used to indicate lignin degradation and increases with increasing lignin oxidation (Otto and Simpson, 2006).

\subsection{Statistical analyses}

All statistical analyses were carried out using SPSS 10.0 (IBM SPSS Inc., USA) and results were plotted using Origin software (Origin Lab Inc., USA). Multivariate statistical approaches such as principle component analysis (PCA) and cluster analysis (CA) are among the most widely used statistical methods in determining the significance of specific parameters, including OC\%, TN\%, mean grain size, clay\% and silt $\%$, total lignin phenol concentrations, DHBA, and the ratios of vanillic acid to vanillin $\left((\mathrm{Ad} / \mathrm{Al})_{\mathrm{V}}\right)$ within a dataset (Pradhan et al., 2009). Interrelationships among the sampling points in different rivers were characterized by cluster analysis using Ward's method (linkage between groups), and similarity measurements were characterized in terms of Euclidian distance, illustrated in dendrograms. Errors listed in tables represent standard deviations for the analytical data. Differences and correlations were evaluated as significant at the level of $p<0.01$.

\section{Results}

\subsection{Hydrological parameters; grain size; and bulk elemental and stable isotopic composition of vegetation, soil, and sediment}

The hydrological parameters for the study area are summarized in Table S1. The salinity of the lower Rajang system varied significantly (from $12 \%$ o to $32 \%$ ) because of saline water intrusion in the estuarine region, but there were limited $\mathrm{pH}$ variations (6.5-7.9). Dissolved oxygen (DO) levels showed significant spatial variations, with the lowest values $\left(2-3 \mathrm{mg} \mathrm{L}^{-1}\right)$ being recorded in the Igan channel, where dense peats were observed, and the higher values (4$6 \mathrm{mg} \mathrm{L}^{-1}$ ) recorded in the other two channels. The salinity of the Simunjan indicated that freshwater dominated, whereas the two other small rivers showed saline water influences. The variation in $\mathrm{pH}$ values among the three small 
rivers decreased from the Sebuyau $(\sim 6.4)$, to the Simunjan $(\sim 5.1)$, and the Maludam $(\sim 3.7)$. The DO concentrations in the three small rivers varied in a low range (average: $2-$ $3 \mathrm{mg} \mathrm{L}^{-1}$ ), with the lowest values in the three systems being around $1.4 \mathrm{mg} \mathrm{L}^{-1}$.

The compositions of bulk sediments from the Rajang and the three small rivers are presented in Tables 1 and S1. The mean grain sizes from the upper Rajang $(212 \pm 47 \mu \mathrm{m})$ were much coarser than those from the lower Rajang $(40 \pm 38 \mu \mathrm{m})$ and the small rivers $(22 \pm 16 \mu \mathrm{m})$. The finest samples $(9 \pm$ $2 \mu \mathrm{m})$ were collected from the Maludam in March 2017. Generally, the samples collected during the dry season were coarser than those from the flood season in the Maludam and Simunjan, but this was not the case for the Sebuyau. The average organic carbon content shows a significant negative relationship with mean grain size among these samples $\left(r^{2}=0.67, p<0.01\right)$.

Mean values of total organic carbon (TOC) concentrations were higher in the peat-draining rivers $(2.2 \pm 0.58 \%$, $2.6 \pm 1.23 \%$, and $2.6 \pm 0.8 \%$ for the Maludam, Sebuyau, and Simunjan, respectively) compared with the lower Rajang $(1.1 \pm 0.5 \%)$, and the lowest values were observed in the upper Rajang $(0.12 \pm 0.02 \%)$. The highest values of OC were measured in plant samples and varied from $30 \%$ to $49 \%$ (Table S2). The mean TOC value in the soil samples was $3.6 \pm 0.6 \%$ (Table S3).

TN content ranged from $0.02 \%$ to $0.17 \%$ in the samples collected from the Rajang, from $0.09 \%$ to $0.37 \%$ in the small rivers, and from $0.73 \%$ to $1.65 \%$ in the vegetation and averaged $0.19 \pm 0.02 \%$ for the soil samples (Tables 1, S2, and S3). Although nitrogen was enriched in the samples from the peat-draining rivers, they still had higher mean $\mathrm{C} / \mathrm{N}$ values $(15.8 \pm 3.7)$ compared with the lower Rajang (11.5 \pm 1.6$)$, while vegetation samples exhibited low $\mathrm{N}$ content and high $\mathrm{C} / \mathrm{N}(\mathrm{C} / \mathrm{N}=56 \pm 34)$.

The most abundant vegetation collected from the Maludam showed relatively depleted carbon isotope ratios $\left(\delta^{13} \mathrm{C}=-31 \%\right.$ o) that were typical of $\mathrm{C}_{3}$ vegetation (Table $\mathrm{S} 2$ ). The detritus samples were also relatively depleted in ${ }^{13} \mathrm{C}\left(\delta^{13} \mathrm{C}=-29.2 \%\right.$; Table 1$)$. The isotope ratios of the peat-draining river's sediments (average $\delta^{13} \mathrm{C}$ varied at $-28.2 \%$ to $-27.4 \%$ o) were comparable with the Rajang's (average $\delta^{13} \mathrm{C}=-28.6 \pm 0.6 \%$ ) (Table 3 ). The $\delta^{13} \mathrm{C}$ values of the soil samples are similar to those of riverine sediments $\left(\delta^{13} \mathrm{C}=-28.4 \% o\right)$.

\subsection{Lignin phenol content}

The lignin phenols obtained after $\mathrm{CuO}$ oxidation are expressed as $\Lambda 8\left(\mathrm{mg}\left(100 \mathrm{mg} \mathrm{OC}^{-1}\right)\right.$, except for the lignin yield $(\Sigma 8)$, which is the sum of $\mathrm{C}+\mathrm{S}+\mathrm{V}$, is expressed as $\mathrm{mg} 10 \mathrm{~g} \mathrm{dw}^{-1}$, and is presented in Fig. 2 as well as Tables 2 and S1-S3. The highest yields were measured in the veg-

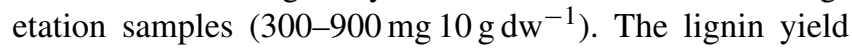
from the soil samples and the three small rivers (average of $\left.\sim 30 \mathrm{mg} 10 \mathrm{~g} \mathrm{dw}^{-1}\right)$ is also higher than that from the Rajang

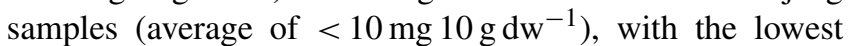
value observed in the upper Rajang $\left(0.16 \mathrm{mg} 10 \mathrm{~g} \mathrm{dw}^{-1}\right.$; Table 2). There are correlations between $\Sigma 8$ and OC\% in each river $\left(r^{2}>0.5\right)$, with the slope decreasing in the following order Maludam $>$ Simunjan $>$ Sebuyau $>$ Rajang (Fig. 2a). The variation in $\Lambda 8$ from various pools shows a similar distribution as the $\Sigma 8$ values. The average concentrations for the vegetation, soil, and the four river systems are approximately $18,8.3$, and $5.4 \mathrm{mg}(100 \mathrm{mg} \mathrm{OC})^{-1}$ for the Rajang; $6.2 \mathrm{mg}(100 \mathrm{mg} \mathrm{OC})^{-1}$ for the Maludam; 7.9 for the Sebuyau; and $7.4 \mathrm{mg}(100 \mathrm{mg} \mathrm{OC})^{-1}$ for the Simunjan.

The $\mathrm{C} / \mathrm{V}$ and $\mathrm{S} / \mathrm{V}$ ratios differ with vegetation type (Fig. 2b). Angiosperm leaves show high S/V (> 1) and C/V ratios $(\sim 0.8)$. Angiosperm wood and root samples show lower $\mathrm{C} / \mathrm{V}$ ratios $(<0.2)$. The detritus samples show intermediate $\mathrm{S} / \mathrm{V}$ ratios $(0.6-1.0)$ and lower $\mathrm{C} / \mathrm{V}$ ratios $(\sim 0.1)$. Soil samples have relatively high $\mathrm{S} / \mathrm{V}(\sim 1.1)$ and low $\mathrm{C} / \mathrm{V}$ $(\sim 0.07)$ values. The four rivers show limited variations in $\mathrm{S} / \mathrm{V}(0.4-0.8)$ and $\mathrm{C} / \mathrm{V}(0.02-0.08)$ ratios. The LPVI values of the fresh plant material range from 113 to 2854 for leaves and 192 to 290 for wood. The values for detritus range from 36 to 228 , and for soil and sediment the values range from 30 to 60 (Table 2).

The ratios of vanillic acid to vanillin $\left((\mathrm{Ad} / \mathrm{Al})_{\mathrm{V}}\right)$ and syringic acid to syringaldehyde $\left((\mathrm{Ad} / \mathrm{Al})_{\mathrm{S}}\right)$ increase slightly from the vegetation samples to the river samples (Table 2). The ratios obtained from the vegetation and soil samples show similar values $\left((\mathrm{Ad} / \mathrm{Al})_{\mathrm{S}}=\sim 0.30 ;(\mathrm{Ad} / \mathrm{Al})_{\mathrm{V}}=\sim\right.$ $0.35)$. The ratios from the small river samples range from 0.41 to 0.58 for $(\mathrm{Ad} / \mathrm{Al})_{\mathrm{V}}$ and 0.30 to 0.36 for $(\mathrm{Ad} / \mathrm{Al})_{\mathrm{S}}$. The values from the lower Rajang are similar to those from the small rivers, but this is not the case for the upper Rajang, where higher $(\mathrm{Ad} / \mathrm{Al})_{\mathrm{S}}$ and $(\mathrm{Ad} / \mathrm{Al})_{\mathrm{V}}$ values were recorded. The two ratios are linearly correlated in all sediment samples $\left(r^{2}=0.68, p<0.05\right)$, except for the samples collected from the Simunjan.

The $\mathrm{P} /(\mathrm{V}+\mathrm{S})$ ratio is low in the vegetation samples, except for the leaf samples $(\mathrm{P} /(\mathrm{V}+\mathrm{S})=0.22)$, which reflects the low $\mathrm{P}$ content in most vegetation (Table 2). However, in some plant samples (Elaeis guineensis Jacq.), we detected relatively high $\mathrm{P}$ content (Table $\mathrm{S} 2$ ). The $\mathrm{P} /(\mathrm{V}+\mathrm{S})$ ratio is $0.28 \pm 0.03$ for the soil samples, $0.18 \pm 0.4$ for the small rivers, $0.17 \pm 0.02$ for the lower Rajang, and $0.51 \pm 0.04$ for the upper Rajang. DHBA is very low in the upper Rajang $(\sim 0.07)$ but higher in the Maludam in the dry season (average value of 0.44). Values in the Simunjan in both seasons are similar to those from the soil samples $(\sim 0.38)$. Higher values of DHBA were measured in the lower Rajang and the Sebuyau in the dry season than in the wet season.

\subsection{Statistical analyses}

The results of cluster and PCA analyses of both bulk geochemical and lignin phenol proxies for all sediments are 


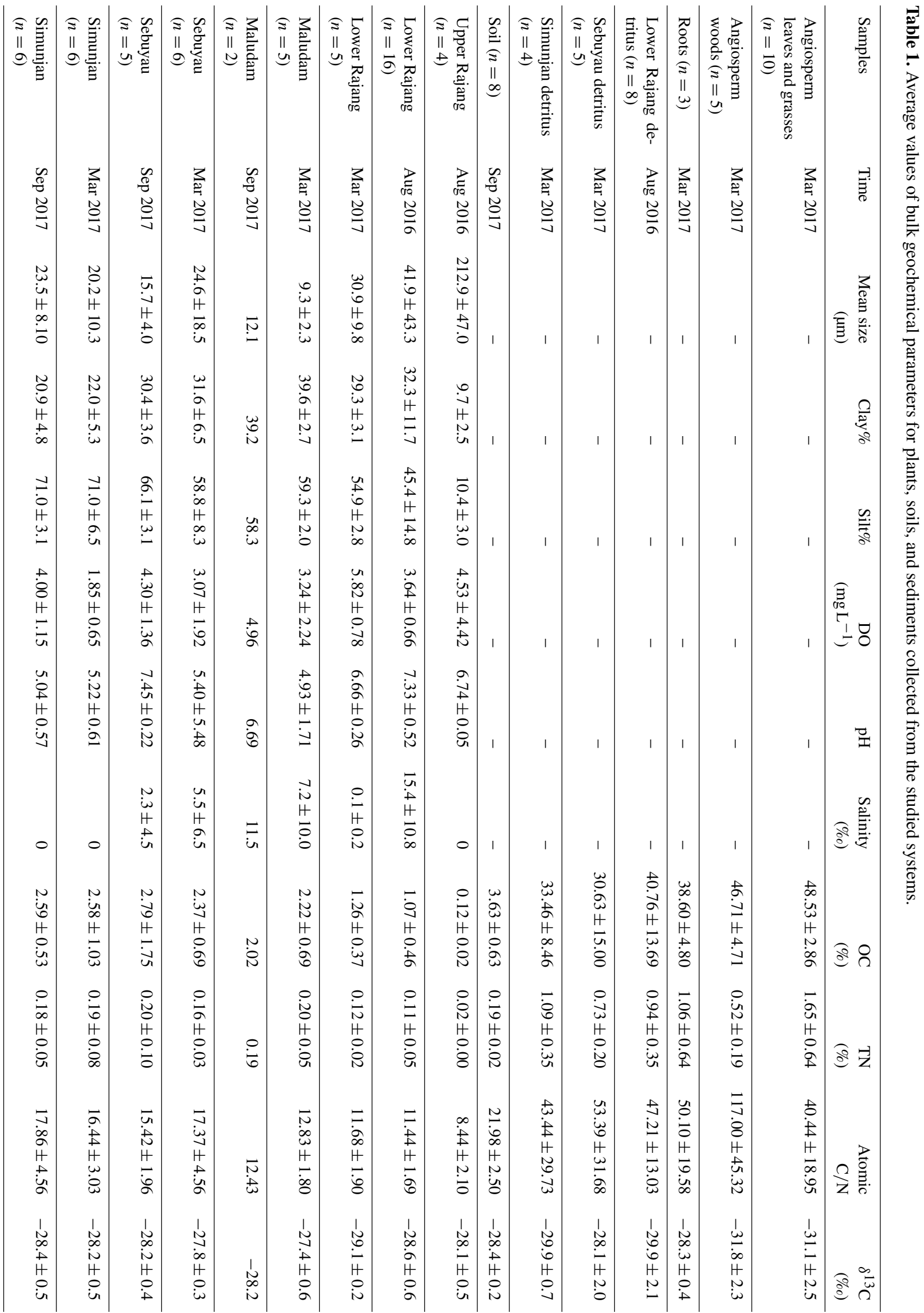




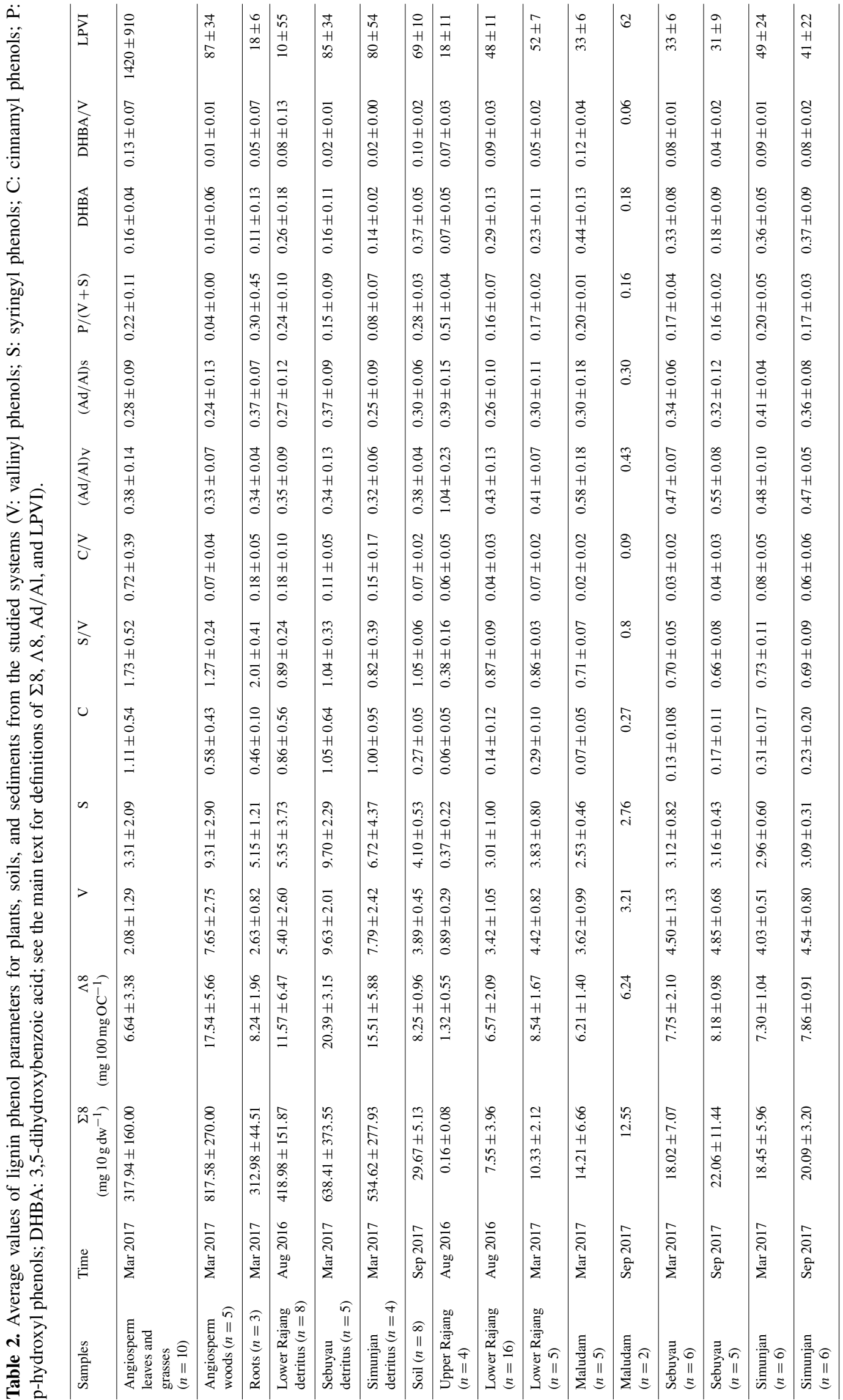



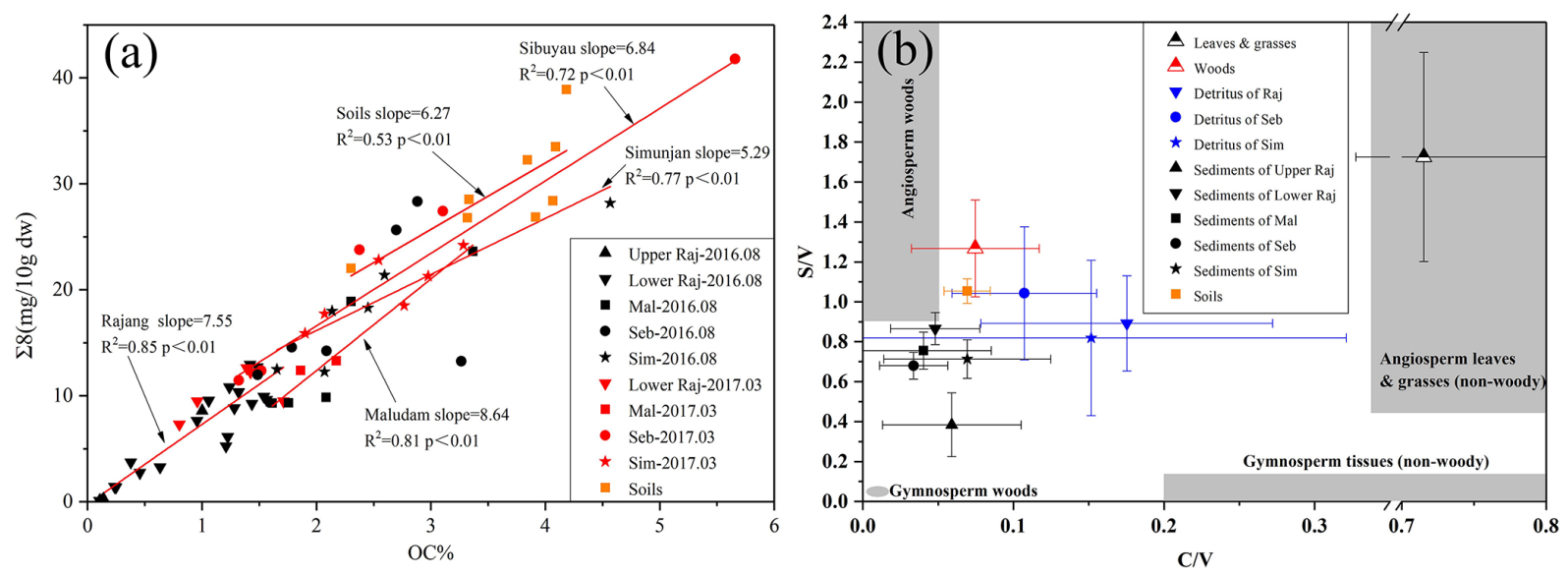

Figure 2. (a) Correlation of OC\% with $\Sigma 8$ among the various studied systems. (b) Variations in S/V versus C/V of different samples from the studied systems. Raj: Rajang; Seb: Sebuyau; Sim: Simunjan; Mal: Maludam.

shown in Fig. 3. Four distinct groups were identified based on the cluster analysis. The Maludam and the tributary of the lower Rajang (Igan) are grouped together, and the Simunjan and Sebuyau are grouped together. The lower Rajang and upper Rajang are separated from each other (Fig. 3a). Similar groupings are evident in the results of the PCA analysis, which was based on the distribution of factors 1 and 2 that represent total loadings of $45 \%$ and $32 \%$, respectively (Fig. 3b). The PCA results implied that factor 1 showed close correlations with the $(\mathrm{Ad} / \mathrm{Al})_{\mathrm{V}}$ ratio and grain size, while factor 2 showed a close correlation with $\Sigma 8$ and OC\%.

\section{Discussion}

\subsection{Comparison with systems worldwide: lignin parameters derived from sediment and peat}

Table 3 summarizes the distribution of bulk and lignin parameters of sediments from typical systems worldwide. Although the TOC values of our studied systems are lower than peat samples, but the concentrations of lignin phenols are comparable and are typically more enriched in lignin phenol compared with other river systems (Table 3; Bianchi et al., 2002; Gandois et al., 2014; Li et al., 2015; Sun et al., 2017; Pradhan et al., 2014; Winterfeld et al., 2015). The TN values of our peat samples are between 2 and 4 times higher than those seen in other systems worldwide, as was also observed in small rivers along India's west coast (Pradhan et al., 2014). The higher values of $\Lambda 8$ found in our studied systems were linked to vegetation types (trees dominated) (Zaccone et al., 2008) and partially caused by peat draining and intense human activity near the watersheds (e.g., land-use change and logging activities), as reported previously (Milliman and Farnsworth, 2011; Moore et al., 2013; Rieley et al., 2008). Much of the peatland neighboring the Simunjan and Sebuyau catchments has been changed to oil palm plan- tations (Martin et al., 2018). The terrigenous OM has been affected by diagenesis, as $(\mathrm{Ad} / \mathrm{Al})_{\mathrm{V}}$ varies markedly among the different systems (Table 3). The $(\mathrm{Ad} / \mathrm{Al})_{\mathrm{V}}$ values of the sediments sampled here are comparable to fresh and only low to medium oxidation. Elevated $(\mathrm{Ad} / \mathrm{Al})_{\mathrm{V}}$ values observed from the Maludam's sediments (March 2017) may also be attributed to source plant variations as observed in a previous study case (Zhu et al., 2019).

\subsection{Origin of sediment organic matter in tropical peat-draining rivers}

The depleted average $\delta^{13} \mathrm{C}$ values $(-31.8 \%$ o to $-28.1 \%$ ) of our vegetation samples indicate an insignificant contribution from $\mathrm{C}_{4}$ plants in the study area (Gandois et al., 2014; Sun et al., 2017). The high $\mathrm{C} / \mathrm{N}$ ratio (64.8) indicates a predominance of terrestrial high plant species (e.g., Nepenthes sp. and Avicennia marina Vierh.). The $\delta^{13} \mathrm{C}$ and $\mathrm{C} / \mathrm{N}$ values $(-27.2 \%$ and 12 , respectively) obtained from the soil and sediments collected near the rivers suggest that terrestrial organic matter is the dominant contributor (Table 1). The cluster and PCA analyses suggest that there are no significant seasonal differences in these rivers. Previous studies have reported that the sediment load from the basin to the delta was not a seasonal pattern; when combined with comparable precipitation during our two sampling seasons, our observations matched this conclusion (Martin et al., 2018; Staub and Gastaldo, 2000). The close correlation of factor 2 with OC\% and $\Sigma 8$ in the PCA suggests factor 2 relates to the source of the organic matter (Fig. 3), as also indicated by the strong correlation between OC\% and $\Sigma 8\left(r^{2}: 0.53-0.85\right)$ (Fig. 2). Correlation of OC\% and $\Sigma 8$ of the Maludam $\left(r^{2}=0.81\right)$ show the highest slope, possibly related to its pristine condition, which promotes better conservation of vegetation in its peat. Furthermore, the differences between the upper and lower Rajang are highlighted by the PCA results (score 1 represents $45 \%$ of the total loading while score 2 is $32 \%$ ) and 


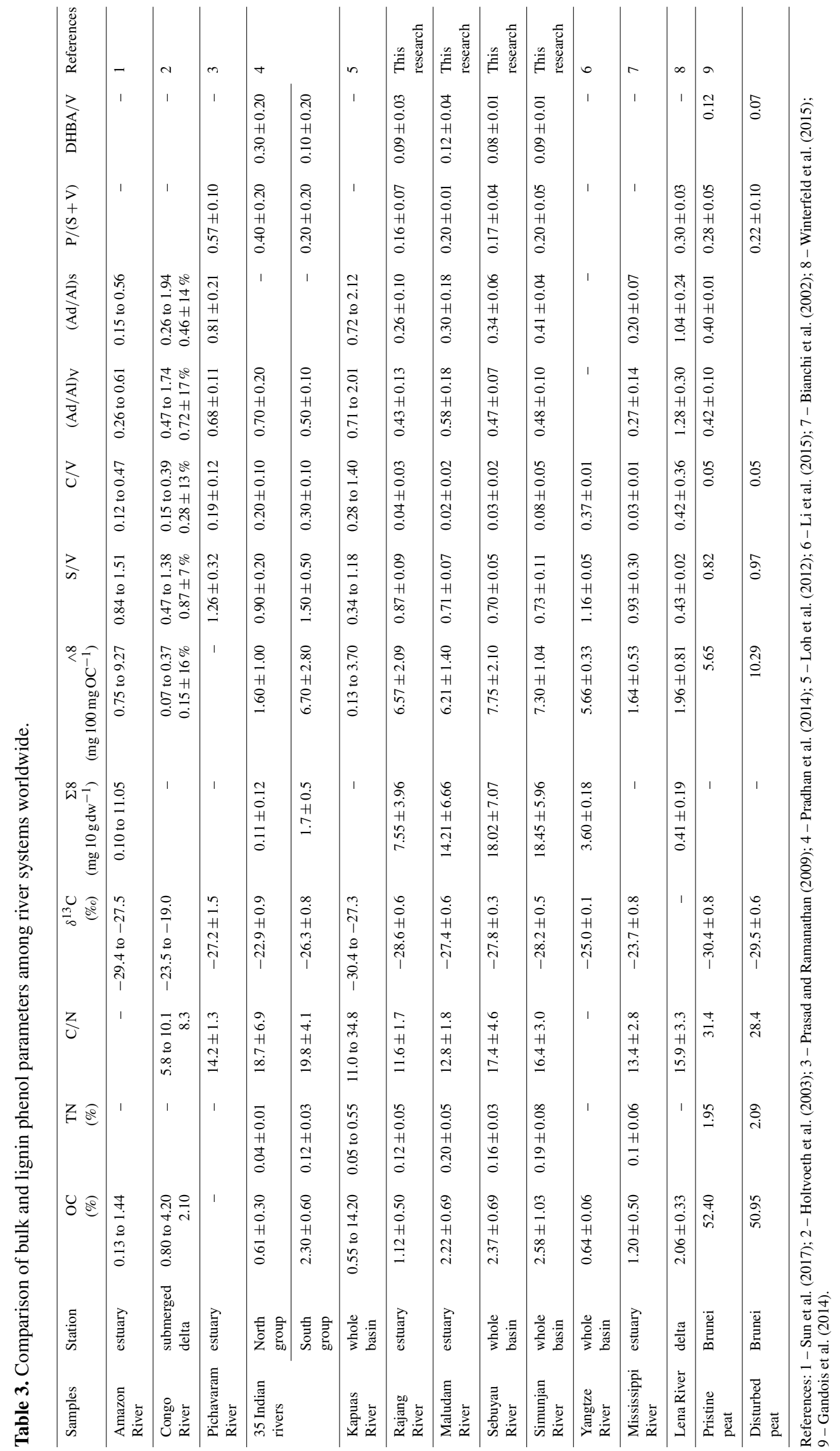



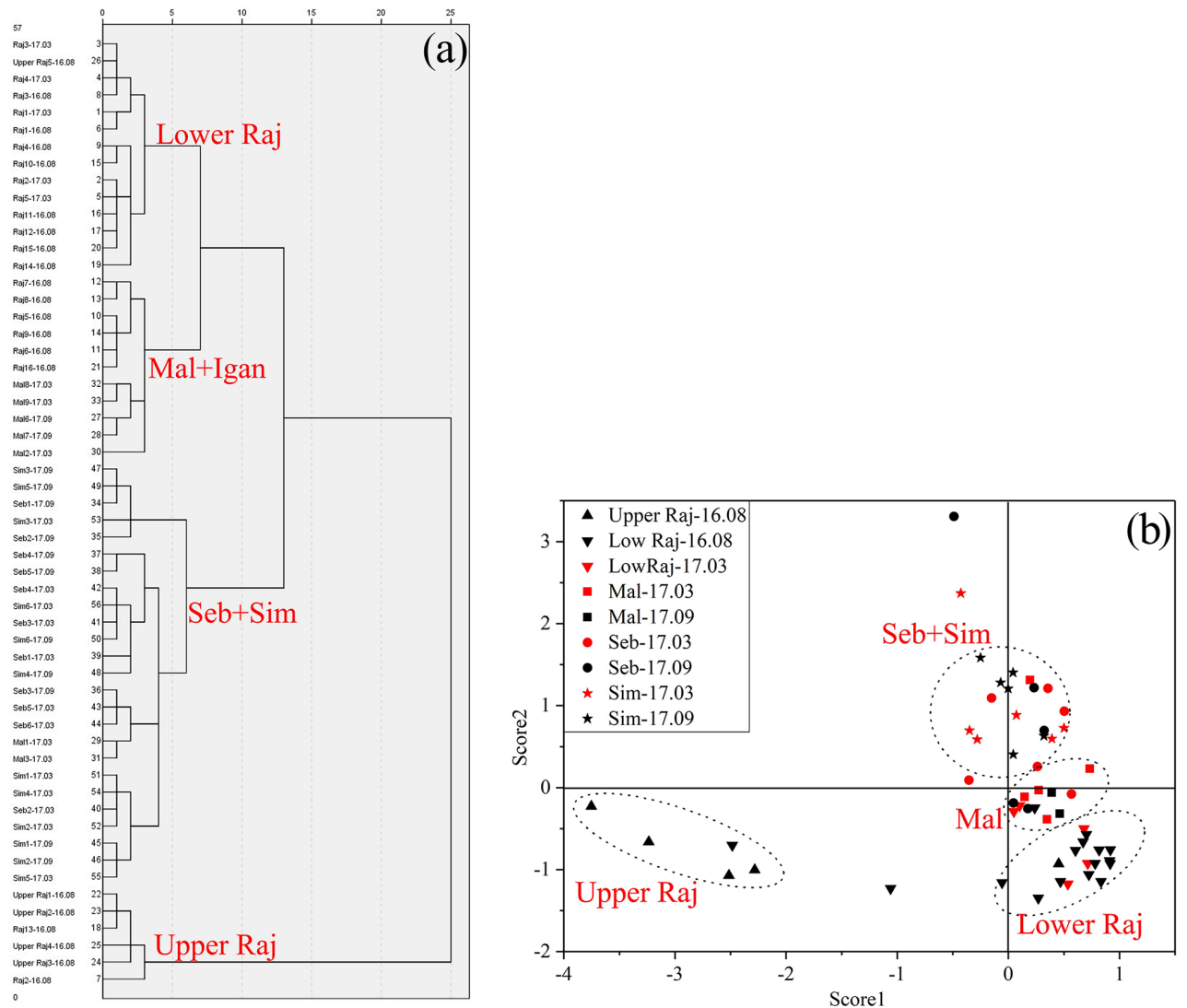

Figure 3. (a) Cluster analysis of the studied systems based on bulk and lignin phenol parameters. (b) Plot of PCA results based on the distribution of scores 1 and 2. Raj: Rajang; Seb: Sebuyau; Sim: Simunjan; Mal: Maludam.

bulk parameters; i.e., the upper Rajang drains a mineral soil, whereas peat is dominant in the delta region. This also explains why the Rajang data do not plot with the other small river systems; the linear relationship between $\delta^{13} \mathrm{C}$ and $\Sigma 8$ for the Rajang $\left(r^{2}=0.92\right)$ forms a distinct group separate from the small rivers $\left(r^{2}=0.59\right)$.

The $\mathrm{S} / \mathrm{V}$ and $\mathrm{C} / \mathrm{V}$ ratios are often used as indicators of the vegetation origin of the lignin fraction, e.g., the woody and nonwoody parts of gymnosperm and angiosperms (Hedges and Mann, 1979). The S/V values $(<0.8)$ of the peatdraining rivers are slightly lower than the values of other peats $(<1.5$ ), but the $\mathrm{C} / \mathrm{V}$ ratios are comparable (Tareq et al., 2004). The differences in these parameters between the sediments and the vegetation and soils, as illustrated in Fig. 2, suggests that they are composed mostly of angiosperm wood. This finding is further confirmed by the LPVI values (gymnosperm wood: 1; nonwoody gymnosperm tissue, 3-27; angiosperm wood: 67-415; non-angiosperm tissue: 176-2782), which are commonly less than 60 in these sediment samples (Tareq et al., 2004). Previous studies have concluded that tropical peats are derived mainly from wood (Anderson, 1983; Gandois et al., 2014). For the Rajang, the LPVI values show a positive linear correlation with $\Lambda 8$ concentrations $\left(r^{2}=0.56\right.$ ); however, for the small rivers (based on mean values, except the samples collected in March 2017 from the Maludam) this relationship shows a negative correlation $\left(r^{2}=0.91\right)$. This suggests that the small rivers receive more lignin derived from woody material, whereas the Rajang has a mixture of sources. The unusual behavior of the Maludam's samples might be related to the dominance of finer-grained sediments when compared with the other rivers because woody material tends to be concentrated in the coarser fraction (Table 1).

$\mathrm{P}$ phenols in the Rajang are derived from lignin, as supported by the significant correlation of the content of $\mathrm{P}$ phenols and lignin content $\left(r^{2}=0.93\right)$. However, there is no correlation between $\mathrm{P}$ phenols and lignin content for the small rivers. All $\mathrm{P} / \mathrm{V}$ values from the samples $(0.13-0.28)$ are higher than the average $\mathrm{P} / \mathrm{V}$ ratio of wood $(0.05)$ but similar to the range observed for leaves (0.16-6.9; Hedges et al., 1986). Considering this, some nonwoody angiosperms are the most likely source of high-P phenols in the small rivers. Combined the composition of $\mathrm{P}$ and $\mathrm{V}$ in plants samples listed in Table S2, we find some dominant species, e.g., Dipterocarpaceae, Bruguiera gymnorrhiza (L.) Poir., Elaeis guineensis Jacq. have relatively high $\mathrm{P} / \mathrm{V}$ ratios in their nonwoody parts. 


\subsection{Transformation of lignin signatures in tropical peat-draining rivers}

$(\mathrm{Ad} / \mathrm{Al})_{\mathrm{V}}$ ratios are often used to evaluate the degradation status of terrestrial $\mathrm{OM}$. The $(\mathrm{Ad} / \mathrm{Al})_{\mathrm{V}}$ ratios for soils reported in previous studies fall within the ranges 0.16-4.36 and $0.1-0.2$ for fresh angiosperm wood and $0.2-0.6$ for nonwoody tissues (Hedges et al., 1988; Opsahl and Benner, 1995; Thevenot et al., 2010). In our study, the variability of the $(\mathrm{Ad} / \mathrm{Al})_{\mathrm{V}}$ ratios obtained from the vegetation, soil, and sediments was limited, with values between 0.3 and 0.58 except from the samples from the upper Rajang $(\sim 1.0)$, which suggests the mild degradation of $\mathrm{OC}_{\text {terr }}$ in most samples. The degradation status of lignin is negatively correlated with the $\Lambda 8$ values $\left(r^{2}=0.73\right)$ in the Rajang, and with a higher degradation signal observed in the upper Rajang, which drains mineral soils with lower lignin levels (Fig. 4a). However, the $\Lambda 8$ values with $(\mathrm{Ad} / \mathrm{Al})_{\mathrm{V}}$ ratios was not as significant in the small river systems as we expected, partially resulting from the variation in $(\mathrm{Ad} / \mathrm{Al})_{\mathrm{V}}$, which could also be controlled by the vegetation source (Fig. 4b). In addition, such a distribution could be related to the grain size effect, as illustrated in the Rajang with high correlation (Fig. 4c) and to a lesser extent but in small rivers (Fig. 4d). Of the sediments sampled here, the upper Rajang samples contain the largest coarse fraction, and the finest sediments are collected from the Maludam in March 2017. The $(\mathrm{Ad} / \mathrm{Al})_{\mathrm{V}}$ ratios increase with the increasing coarse fraction of the sediments in the Rajang, which is typically also observed in other systems (Bianchi et al., 2002; Li et al., 2015; Sun et al., 2017) (Fig. 4c). The variation in $(\mathrm{Ad} / \mathrm{Al})_{\mathrm{V}}$ ratios with mean size of the sediments in the small rivers is not as significant as in the Rajang (Fig. 4d). Selective sorption of acid to aldehyde might affect the variation in the $(\mathrm{Ad} / \mathrm{Al})_{\mathrm{V}}$ ratio in the small river systems (Hernes et al., 2007). Additionally, the relatively fresh condition of the OM in the Maludam samples (in September 2017) might be related to the fluvial supply of fresh vegetation.

The syringyl and cinnamyl series are preferentially degraded when compared with the vallinyl series, resulting in a decrease in the $\mathrm{S} / \mathrm{V}$ and $\mathrm{C} / \mathrm{V}$ ratios during lignin degradation (Goñi and Hedges, 1995; Opsahl and Benner, 1995). Our samples show a negative linear relationship between the $\mathrm{S} / \mathrm{V}$ and $(\mathrm{Ad} / \mathrm{Al})_{\mathrm{V}}$ ratios in the Rajang samples $\left(r^{2}=0.85\right.$; Fig. 5a). However, the variation in the $\mathrm{S} / \mathrm{V}$ and $(\mathrm{Ad} / \mathrm{Al})_{\mathrm{V}}$ ratios in the small rivers is limited, with a scattering decrease trend (Fig. 5b). Both correlations indicate that the decrease in the $\mathrm{S} / \mathrm{V}$ ratios is linked to degradation, and this suggests that we should be cautious when using S/V ratios for source evaluation in this study.
Previous studies demonstrated that lignin mineralization in humid tropical forest soils is dominated by methoxyl-C mineralization under aerobic and fluctuating redox conditions (Hall et al., 2015). Demethylation reduces the yield of methoxylated phenols ( $\mathrm{V}$ and $\mathrm{S}$ phenols) but does not affect $\mathrm{P}$ phenols. Therefore, the $\mathrm{P} /(\mathrm{S}+\mathrm{V})$ ratio can be used as an indicator of lignin transformation (Dittmar and Kattner, 2003). However, in this study the ratio of $\mathrm{P} /(\mathrm{S}+\mathrm{V})$ in most sediment samples did not vary greatly $(\sim 0.2)$. Although there was a linear correlation between the $\mathrm{P} /(\mathrm{S}+\mathrm{V})$ and $(\mathrm{Ad} / \mathrm{Al})_{\mathrm{V}}$ ratios among all the sediments $\left(r^{2}=0.89\right)$, no clear trend was observed for the small rivers, which may suggest both parameters have more links to the source rather than a diagenetic process in these systems.

\subsection{Impact of environmental parameters on lignin dynamics}

It is well-explored that bulk organic matter composition and degradation are influenced by many environmental factors such as climate, grain size, mineral composition, soil characteristics, land-use changes, logging, and biomass burning (Hernes et al., 2007; Gandois et al., 2014; Sun et al., 2017; Thevenot et al., 2010). Most Southeast Asian peat-draining rivers are impacted by human activities such as deforestation, urbanization, and damming (Milliman and Farnsworth, 2011). The PCA analysis revealed that the behavior of lignin in the Rajang is substantially different from that in the three peat-draining rivers, and especially in the upper Rajang, which drains through a mineral soil with low $\Lambda 8$ values and strong degradation (Figs. 3 and 4), since it was recently shown that lignin could decompose as fast as litter bulk carbon in mineral soils (Duboc et al., 2014). In the delta region, most parameters were quite comparable, except $\Sigma 8$ and OC\% (Table S1). The higher values of $\Sigma 8$ and OC\% were observed in Simunjan and Sebuyau, where land use and drainage observed. Usually, land use and drainage of tropical peat will accelerate the loss of vegetation and OC degradation (Kononen et al., 2016); here it may be explained by the high content of OC and lignin in oil palm, which is the major plantation in both regions.

In this study, the OC content increases with decreasing grain size, implying that fine sediments, with larger specific surface areas that are rich in clay, contain more OM than coarser sediments, as reported previously (Sun et al., 2017). Increasing $(\mathrm{Ad} / \mathrm{Al})_{V}$ values are observed in the $\mathrm{Ra}$ jang with increasing grain size, which suggests that lignin associated with larger mineral particles is more strongly degraded. This observation indicates the preferential preservation of lignin in finer-grained sediments, resulting from their ability to provide better protection against further oxidative degradation (Killops and Killops, 2005). For the small river systems, the $(\mathrm{Ad} / \mathrm{Al})_{\mathrm{V}}$ ratios inattentively decrease with increasing grain size, corresponding to the increasing $\Sigma 8$ values (Fig. 4b and d). Such trends have been described by 

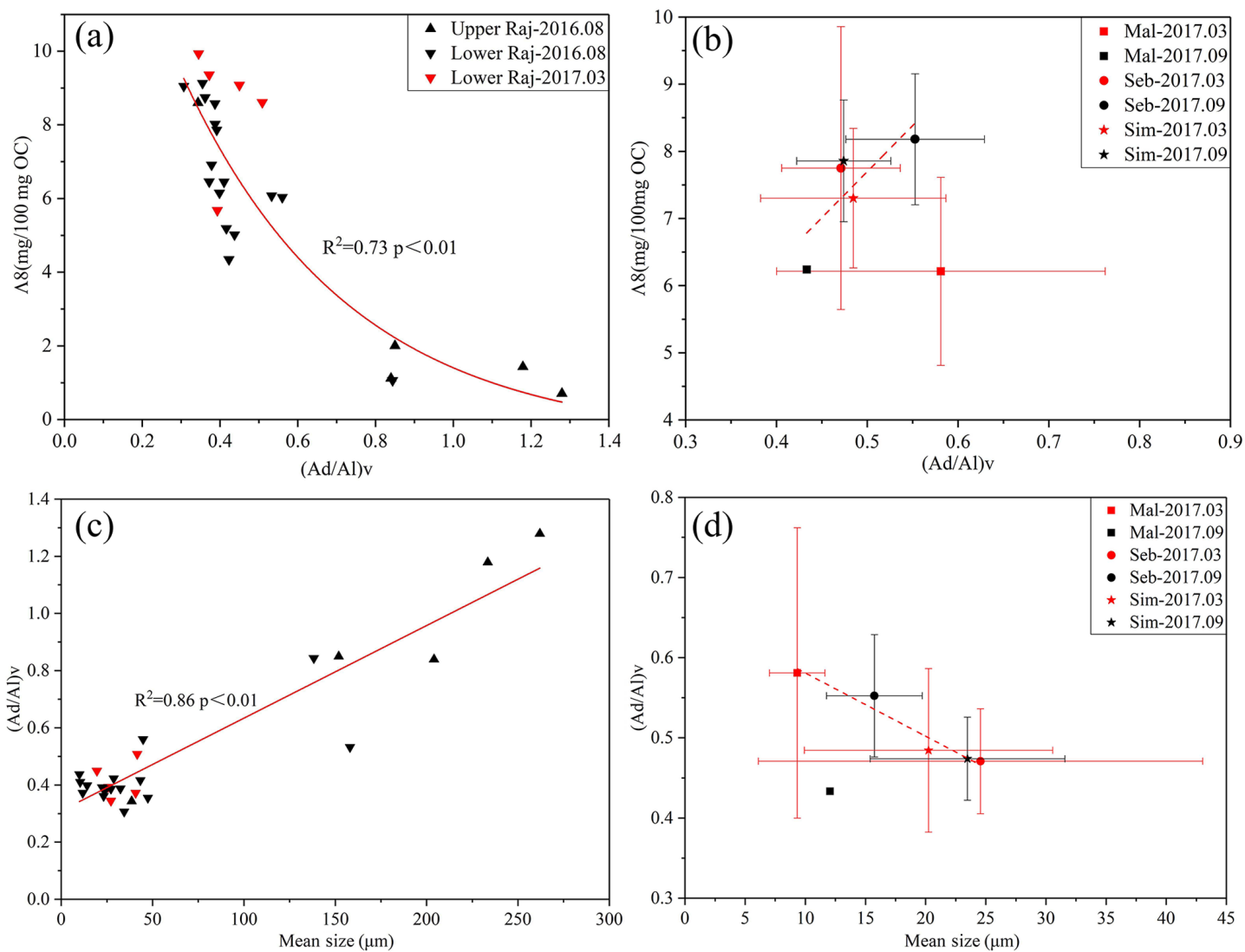

Figure 4. Variation in $(\mathrm{Ad} / \mathrm{Al})_{\mathrm{V}}$ with $\Lambda 8$ values of sediments from (a) the Rajang and (b) the small river systems. Variation in $(\mathrm{Ad} / \mathrm{Al})_{\mathrm{V}}$ with mean sediment grain size for (c) the Rajang and (d) the small river systems.
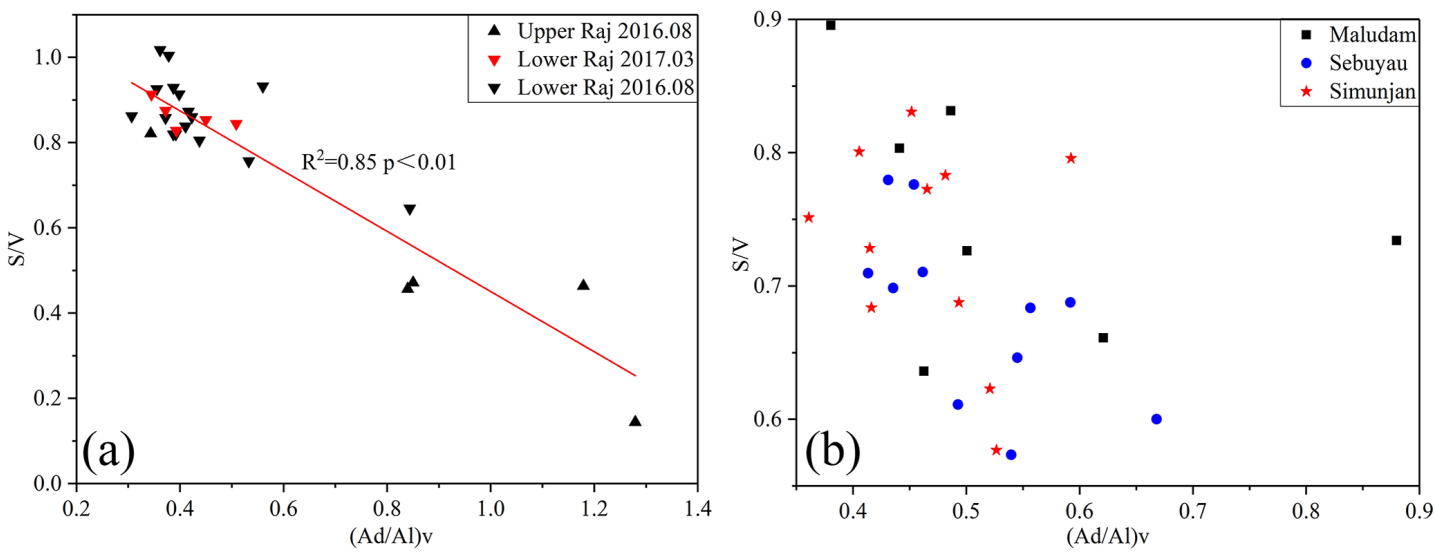

Figure 5. Relationship between $(\mathrm{Ad} / \mathrm{Al})_{\mathrm{V}}$ and $\mathrm{S} / \mathrm{V}$ ratios based on average values of the various systems for (a) the Rajang and (b) the small river systems.

Keil et al. (1998) and Tesi et al. (2016), who found that lower $(\mathrm{Ad} / \mathrm{Al})_{\mathrm{V}}$ values were present in the coarser fractions due to the less efficient processing of plant remains prior to deposition. The sediments collected from the three small peat-draining rivers (except samples from the Maludam in September 2017) could contain limited amounts of plant de- bris, in which case fresh plant tissue would have been incorporated into the coarser sediment fractions, leading to the low $(\mathrm{Ad} / \mathrm{Al})_{\mathrm{V}}$ values. However, the variation in $\Sigma 8$ values does not support this speculation, and therefore we conclude that the selective sorption of acid to aldehyde could explain the elevated $(\mathrm{Ad} / \mathrm{Al})_{\mathrm{V}}$ ratios recorded in the fine fraction. The 

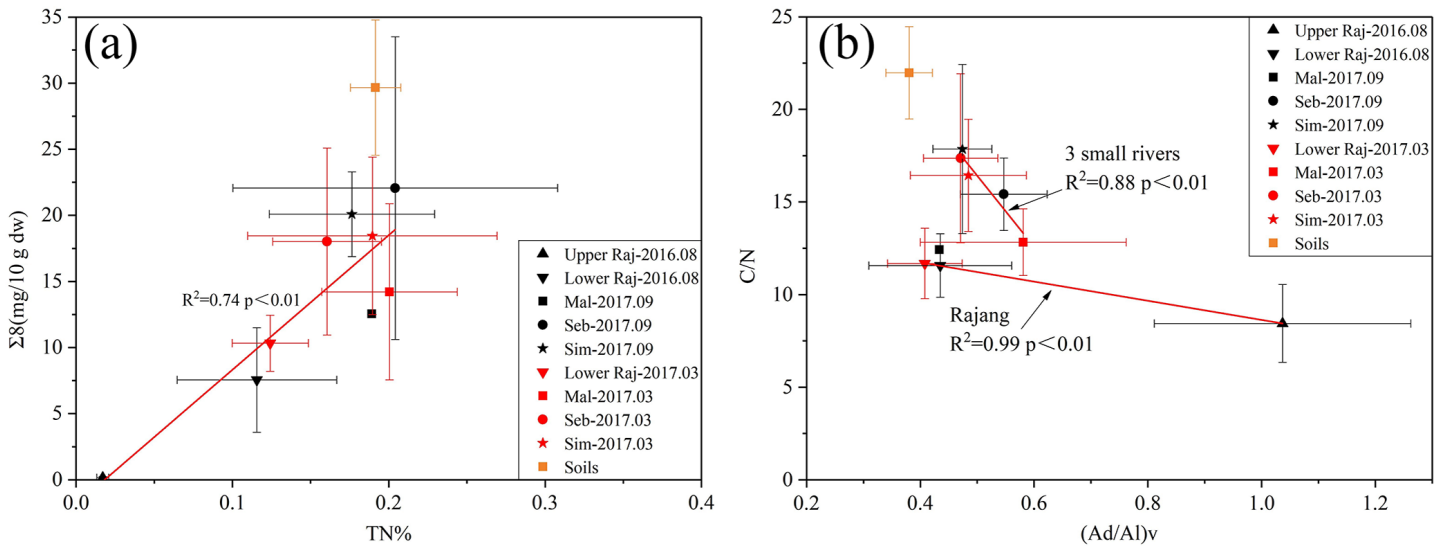

Figure 6. (a) Correlation of $\mathrm{TN} \%$ with $\Sigma 8$ based on average values of the studied systems. (b) Correlation of $(\mathrm{Ad} / \mathrm{Al})_{\mathrm{V}}$ with $\mathrm{C} / \mathrm{N}$ ratio based on average values of the studied systems.

different grain-size effects on $\mathrm{OC}_{\text {terr }}$ composition, as seen when comparing the Rajang with the small rivers, suggests that there are other processes (microbial process, logging, etc.) working on $\mathrm{OC}_{\text {terr }}$ in these two systems that cause postdepositional changes in the $\mathrm{OC}_{\text {terr }}$ characteristics.

Tropical soils are reported as being naturally poor in $\mathrm{N}$ and $\mathrm{P}$, but some studies have shown that with intensive management (land use and deforestation) they tend to become rich in recalcitrant compounds, since nitrogen content tends to stimulate decomposition of low-lignin litter with decomposer microbes but usually decreases the activity of lignolytic enzymes and inhibits decomposition of high-lignin litter (Knorr et al., 2005; Thevenot et al., 2010). In our study, we found a higher TN\% in the small rivers compared with the Rajang. A significant correlation between $\Sigma 8$ and TN\% $\left(r^{2}=0.74\right)$ is observed in all systems, which might suggest a contribution from plant litter affecting both parameters (Fig. 6a). The relation of $(\mathrm{Ad} / \mathrm{Al})_{\mathrm{V}}$ ratios with $\mathrm{C} / \mathrm{N}$ ratios of the $\mathrm{Ra}-$ jang appears correlated $\left(r^{2}=0.34\right)$. For the comparison, average values were applied to two systems, we found the average $(\mathrm{Ad} / \mathrm{Al})_{\mathrm{V}}$ ratios had certain correlation with the average $\mathrm{C} / \mathrm{N}$ ratios but with different slopes for the Rajang and the small rivers (Fig. 6b). Quicker decline of $\mathrm{C} / \mathrm{N}$ ratios related to slower lignin degradation in small rivers could be related to the expected impact of nitrogen on lignin degradation (Dignac et al., 2002; Thevenot et al., 2010). A high N content will inhibit fungal lignin biodegradation (Fog, 1988; Osono and Takeda, 2001), and this explains why higherlignin phenols with moderately degraded characteristics were observed in the small river systems in which higher TN\% was recorded. The exceptional data were collected during September 2017, which was a time of saline water intrusion.

Large-scale land reclamation, including deforestation and urbanization, has taken place in Southeast Asia over the past few decades (Miettinen et al., 2016). Logging activities have had a significant influence on peat decomposition processes and the quality of organic matter inputs (Hoscilo et al., 2011; Hooijer et al., 2012; Gandois et al., 2014). Gandois et al. (2013) reported an increase in the $\mathrm{N}$ content at a deforested site and concluded that it was caused by an increase in the microbial deposition of peat. The lignin yield $(\Sigma 8)$ is closely correlated with the OC\% in the different rivers (Fig. 2). The highest yield was observed at the Maludam, which confirmed the significant contribution of plant litter and better preservation due to the low $\mathrm{pH}$ and DO levels, especially woody carbon. However, the relatively high yield in the Rajang compared with the other two disturbed peatdraining rivers (i.e., the Simunjan and Sebuyau) suggests an additional source of lignin, which might implicate the addition of logging residue to the Rajang systems, as proposed by Gandois et al. (2014).

\section{Conclusions}

We used sediment grain size data, TOC contents, the stable carbon isotopic composition of organic matter, and lignin phenol concentrations to investigate the characteristics of $\mathrm{OC}_{\text {terr }}$ in a tropical peat-draining river system, as well as its fate and environmental controls. The depleted $\delta^{13} \mathrm{C}$ levels of all of the sediment samples demonstrate that contributions from $\mathrm{C}_{3}$ plants dominated the $\mathrm{OC}_{\text {terr }}$ in the study region. The lignin composition of the organic matter indicates that the most important plant sources of organic matter were woody angiosperm $\mathrm{C}_{3}$ plants, especially in the three small rivers. Our cluster and PCA analyses show no distinct seasonal variations in the bulk and lignin compositional signatures in the study area, although the upper Rajang receives contributions from mineral soils with unique lignin parameters and a coarser grain size. Both the bulk organic matter parameters and the lignin compositions seemed to be correlated to the grain size of the riverbed sediments. The $(\mathrm{Ad} / \mathrm{Al})_{V}$ ratios increased with decreasing mean size of the sediments from the small rivers. Selective sorption of acid to aldehyde might 
affect the variation in the $(\mathrm{Ad} / \mathrm{Al})_{\mathrm{V}}$ ratio in the small river systems. Our samples show a negative linear relationship between the $\mathrm{S} / \mathrm{V}$ and $(\mathrm{Ad} / \mathrm{Al})_{\mathrm{V}}$ ratios in the Rajang samples, which implies that the decrease in $\mathrm{S} / \mathrm{V}$ ratios is linked to degradation. The $(\mathrm{Ad} / \mathrm{Al})_{\mathrm{V}}$ ratios appear to be related to the $\mathrm{C} / \mathrm{N}$ ratio in the Rajang and the small rivers. A high $\mathrm{N}$ content will inhibit fungal lignin biodegradation, which might explain higher-lignin phenols with moderately degraded processes observed in the small river systems where a higher $\mathrm{TN} \%$ is recorded. Most of the $\mathrm{OC}_{\text {terr }}$ discharged from the Rajang and small river systems was composed of woody angiosperm plants, and the terrestrial organic matter undergoes limited diagenetic alteration before deposition and could potentially become a significant regional carbon source to the atmosphere after extensive degradation. This study provides new insights into the amount of terrestrial OC preserved in the tropical delta region of southeastern Borneo, as well as into the biogeochemical transformation of OM from terrestrial sources to marine sink across this region.

Data availability. The datasets in the present study are available from the corresponding author on reasonable request.

Supplement. The supplement related to this article is available online at: https://doi.org/10.5194/bg-16-4517-2019-supplement.

Author contributions. YW, JZ, MM, and AM conceptualized the research project and planned the field expeditions. JZ, MM, and AM obtained research funding. JZ, KZ, JS, MM, MFM, ESAS, and AM collected samples and $\mathrm{KZ}$ and $\mathrm{YW}$ analyzed the samples. YW, $\mathrm{KZ}$, and $\mathrm{JZ}$ processed and analyzed the data. All authors contributed to data interpretation and to the writing of the manuscript.

Competing interests. The authors declare that they have no conflict of interest.

Special issue statement. This article is part of the special issue "Biogeochemical processes in highly dynamic peat-draining rivers and estuaries in Borneo". It is not associated with a conference.

Acknowledgements. The present research was kindly supported by the Newton-Ungku Omar Fund (NE/P020283/1), the Natural Science Foundation of China (41530960), China Postdoctoral Science Foundation (2018M630416), MOHE FRGS 15 (FRGS/1/2015/WAB08/SWIN/02/1), and the SKLEC Open Research Fund (SKLEC-KF201610). The authors would like to thank the Sarawak Forestry Department and Sarawak Biodiversity Centre for permission to conduct collaborative research in Sarawak waters under permit no. NPW.907.4.4 (Jld.14)-161 and park permit nos. WL83/2017 and SBC-RA-0097-MM. Lukas Chin and the SeaWonder crew are acknowledged for their support during the cruises.
Zhuoyi Zhu, Lijun Qi, and the Marine Biogeochemistry Group are especially acknowledged for their contribution and support during the sampling trips and laboratory analysis. We also acknowledge the constructive suggestions of Tim Jennerjahn, David Burdige, and the anonymous referee, which improved the original manuscript.

Financial support. This research has been supported by the Newton-Ungku Omar Fund (grant no. NE/P020283/1), the Natural Science Foundation of China (grant no. 41530960), China Postdoctoral Science Foundation (grant no. 2018M630416), MOHE FRGS 15 (grant no. FRGS/1/2015/WAB08/SWIN/02/1), and the SKLEC Open Re40 search Fund (grant no. SKLEC-KF201610).

Review statement. This paper was edited by Tim Jennerjahn and reviewed by David Burdige and one anonymous referee.

\section{References}

Alin, S. R., Aalto, R., Goñi, M. A., Richey, J. E., and Dietrich, W. E.: Biogeochemical characterization of carbon sources in the Strickland and Fly rivers, Papua New Guinea, J. Geophy. Res.Earth, 113, F01S05, https://doi.org/10.1029/2006JF000625, 2008.

Alkhatib, M., Jennerjahn, T. C., and Samiaji, J.: Biogeochemistry of the Dumai River estuary, Sumatra, Indonesia, a tropical black-water river, Limnol. Oceanogr., 52, 2410-2417, https://doi.org/10.4319/lo.2007.52.6.2410, 2007.

Anderson, J. A. R.: The tropical peat swamps of western Malesia. Ecosystems of the World 4B, Mires: Swamp, Bog, Fen and Moor, Reg. Stud., 181-199, 1983.

Aufdenkampe, A. K., Mayorga, E., Hedges, J. I., Llerena, C., Quay, P. D., Gudeman, J., Krusche, A. V., and Richey, J. E.: Organic matter in the Peruvian headwaters of the Amazon: Compositional evolution from the Andes to the lowland Amazon mainstem, Org. Geochem., 38, 337-364, https://doi.org/10.1016/j.orggeochem.2006.06.003, 2007.

Aufdenkampe, A. K., Mayorga, E., Raymond, P. A., Melack, J. M., Doney, S. C., Alin, S. R., Aalto, R. E., and Yoo, K.: Riverine coupling of biogeochemical cycles between land, oceans, and atmosphere, Front. Ecol. Environ., 9, 53-60, https://doi.org/10.1890/100014, 2011.

Bao, H., Lee, T. Y., Huang, J. C., Feng, X., Dai, M., and Kao, S. J.: Importance of Oceanian small mountainous rivers (SMRs) in global land-to-ocean output of lignin and modern biospheric carbon, Sci. Rep.-UK, 5, 16217, https://doi.org/10.1038/srep16217, 2015.

Battin, T. J., Luyssaert, S., Kaplan, L. A., Aufdenkampe, A. K., Richter, A., and Tranvik, L. J.: The boundless carbon cycle, Nat. Geosci., 2, 598-600, https://doi.org/10.1038/ngeo618, 2009.

Baum, A., Rixen, T., and Samiaji, J.: Relevance of peat draining rivers in central Sumatra for the riverine input of dissolved organic carbon into the ocean, Estuar. Coast. Shelf S., 73, 563-570, https://doi.org/10.1016/j.ecss.2007.02.012, 2007.

Benner, R., Maccubbin, A. E., and Hodson, R. E.: Anaerobic biodegradation of the lignin and polysaccharide components of 
lignocellulose and synthetic lignin by sediment microflora, Appl. Environ. Microb., 47, 998-1004, 1984.

Bianchi, T. S. and Bauer, J. E.: 5.03 - particulate organic carbon cycling and transformation, Treatise on estuarine and coastal science, 5, 69-117, 2011.

Bianchi, T. S., Mitra, S., and McKee, B. A.: Sources of terrestriallyderived organic carbon in lower Mississippi River and Louisiana shelf sediments: implications for differential sedimentation and transport at the coastal margin, Mar. Chem., 77, 211-223, https://doi.org/10.1016/S0304-4203(01)00088-3, 2002.

Burdige, D. J.: Burial of terrestrial organic matter in marine sediments: A re-assessment, Global Biogeochem. Cy., 19, GB4011, https://doi.org/10.1029/2004GB002368, 2005.

Cook, S., Peacock, M., Evans, C. D., Page, S. E., Whelan, M. J., Gauci, V., and Kho, L. K.: Quantifying tropical peatland dissolved organic carbon (DOC) using UV-visible spectroscopy, Water Res., 115, 229-235, https://doi.org/10.1016/j.watres.2017.02.059, 2017.

Dignac, M. F., Knicker, H., and Kögel-Knabner, I.: Effect of N content and soil texture on the decomposition of organic matter in forest soils as revealed by solid-state CPMAS NMR spectroscopy, Org. Geochem., 33, 1715-1726, 2002.

Dittmar, T. and Lara, R. J.: Molecular evidence for lignin degradation in sulfate-reducing mangrove sediments (Amazonia, Brazil), Geochim. Cosmochim. Ac., 65, 1417-1428, 2001.

Dittmar, T. and Kattner, G.: The biogeochemistry of the river and shelf ecosystem of the Arctic Ocean: a review, Mar. Chem., 83, 103-120, https://doi.org/10.1016/S0304-4203(03)00105-1, 2003.

Dommain, R., Couwenberg, J., Glaser, P. H., Joosten, H., and Suryadiputra, I. N. N.: Carbon storage and release in Indonesian peatlands since the last deglaciation, Quaternary Sci. Rev., 97, 1-32, https://doi.org/10.1016/j.quascirev.2014.05.002, 2014.

Drenzek, N. J., Montluçon, D. B., Yunker, M. B., Macdonald, R. W., and Eglinton, T. I.: Constraints on the origin of sedimentary organic carbon in the Beaufort Sea from coupled molecular ${ }^{13} \mathrm{C}$ and ${ }^{14} \mathrm{C}$ measurements, Mar. Chem., 103, 146-162, https://doi.org/10.1016/j.marchem.2006.06.017, 2007.

Duboc, O., Dignac, M. F., Djukic, I., Zehetner, F., Gerzabek, M. H., and Rumpel, C.: Lignin decomposition along an Alpine elevation gradient in relation to physicochemical and soil microbial parameters, Glob. Change Biol., 20, 2272-2285, 2014.

Feng, X., Feakins, S. J., Liu, Z., Ponton, C., Wang, R. Z., Karkabi, E., Galy, V., Berelson, W. M., Nottingham, A. T., Meir, P., and West, A. J.: Source to sink: Evolution of lignin composition in the Madre de Dios River system with connection to the Amazon basin and offshore, J. Geophys. Res.-Biogeo., 121, 1316-1338, https://doi.org/10.1002/2016JG003323, 2016.

Fog, K.: The effect of added nitrogen on the rate of decomposition of organic matter, Biol. Rev., 63, 433-462, 1988.

Gandois, L., Cobb, A. R., Hei, I. C., Lim, L. B. L., Salim, K. A., and Harvey, C. F.: Impact of deforestation on solid and dissolved organic matter characteristics of tropical peat forests: implications for carbon release, Biogeochemistry, 114, 183-199, 2013.

Gandois, L., Teisserenc, R., Cobb, A. R., Chieng, H. I., Lim, L. B. L., Kamariah, A. S., Hoyt, A., and Harvey, C. F.: Origin, composition, and transformation of dissolved organic matter in tropical peatlands, Geochim. Cosmochim. Ac., 137, 35-47, https://doi.org/10.1016/j.gca.2014.03.012, 2014.
Goldsmith, S. T., Carey, A. E., Lyons, W. B., Kao, S.-J., Lee, T. Y., and Chen, J.: Extreme storm events, landscape denudation, and carbon sequestration: Typhoon Mindulle, Choshui River, Taiwan, Geology, 36, 483-486, https://doi.org/10.1130/g24624a.1, 2008.

Goñi, M. A. and Hedges, J. I.: Sources and reactivities of marinederived organic matter in coastal sediments as determined by alkaline $\mathrm{CuO}$ oxidation, Geochim. Cosmochim. Ac., 59, 29652981, 1995.

Goñi, M. A. and Montgomery, S.: Alkaline $\mathrm{CuO}$ oxidation with a microwave digestion system: Lignin analyses of geochemical samples, Anal. Chem., 72, 3116-3121, 2000.

Goñi, M. A., Ruttenberg, K. C., and Eglinton, T. I.: A reassessment of the sources and importance of land-derived organic matter in surface sediments from the Gulf of Mexico, Geochim. Cosmochim. Ac., 62, 3055-3075, 1998.

Goñi, M. A., Yunker, M. B., Macdonald, R. W., and Eglinton, T. I.: The supply and preservation of ancient and modern components of organic carbon in the Canadian Beaufort Shelf of the Arctic Ocean, Mar. Chem., 93, 53-73, https://doi.org/10.1016/j.marchem.2004.08.001, 2005.

Goñi, M. A., Monacci, N., Gisewhite, R., Ogston, A., Crockett, J., and Nittrouer, C.: Distribution and sources of particulate organic matter in the water column and sediments of the Fly River Delta, Gulf of Papua (Papua New Guinea), Estuar. Coast. Shelf S., 69, 225-245, https://doi.org/10.1016/j.ecss.2006.04.012, 2006.

Hall, S. J., Silver, W., Timokhin, V. I., and Hammel, K. E.: Lignin decompositions is sustained under fluctuating redox conditions in humid-tropical forest soils, Glob. Change Biol., 21, 28182828, 2015.

Hedges, J. I. and Ertel, J. R.: Characterization of lignin by gas capillary chromatography of cupric oxide oxidation products, Anal. Chem., 54, 174-178, 1982.

Hedges, J. I. and Mann, D. C.: The characterization of plant tissues by their lignin oxidation products, Geochim. Cosmochim. Ac., 43, 1803-1807, 1979.

Hedges, J. I., Cowie, G. L., Ertel, J. R., Barbour, R. J., and Hatcher, P. G.: Degradation of carbohydrates and lignins in buried woods, Geochim. Cosmochim. Ac., 49, 701-711, 1985.

Hedges, J. I., Clark, W. A., Quay, P. D., Richey, J. E., Devol, A. H., and Santos, M.: Compositions and fluxes of particulate organic material in the Amazon River ${ }^{1}$, Limnol. Oceanogr., 31, 717-738, 1986.

Hedges, J. I., Blanchette, R. A., Weliky, K., and Devol, A. H.: Effects of fungal degradation on the $\mathrm{CuO}$ oxidation products of lignin: a controlled laboratory study, Geochim. Cosmochim. Ac., 52, 2717-2726, 1988.

Hernes, P. J. and Benner, R.: Transport and diagenesis of dissolved and particulate terrigenous organic matter in the North Pacific Ocean, Deep-Sea Res. Pt. I, 49, 2119-2132, 2002.

Hernes, P. J., Robinson, A. C., and Aufdenkampe, A. K.: Fractionation of lignin during leaching and sorption and implications for organic matter "freshness", Geophys. Res. Lett., 34, L17401, https://doi.org/10.1029/2007g1031017, 2007.

Hernes, P. J., Dyda, R. Y., and McDowell, W. H.: Connecting tropical river DOM and POM to the landscape with lignin, Geochim. Cosmochim. Ac., 219, 143-159, https://doi.org/10.1002/2017JG003935, 2017.

Holtvoeth, J., Wagner, T., and Schubert, C. J.: Organic matter in river-influenced continental margin sediments: The land- 
ocean and climate linkage at the Late Quaternary Congo fan (ODP Site 1075), Geochem. Geophy. Geosy., 4, 1109, https://doi.org/10.1029/2003GC000590, 2003.

Hooijer, A., Page, S., Jauhiainen, J., Lee, W. A., Lu, X. X., Idris, A., and Anshari, G.: Subsidence and carbon loss in drained tropical peatlands, Biogeosciences, 9, 1053-1071, https://doi.org/10.5194/bg-9-1053-2012, 2012

Hoscilo, A., Page, S. E., Tansey, K. J., and Rieley, J. O.: Effect of repeated fires on land-cover change on peatland in southern Central Kalimantan, Indonesia, from 1973 to 2005, Int. J. Wildland Fire, 20, 578-588, 2011.

Houghton, R. A., Skole, D. L., Nobre, C. A., Hackler, J. L., Lawrence, K. T., and Chomentowski, W. H.: Annual fluxes of carbon from deforestation and regrowth in the Brazilian Amazon, Nature, 403, 301-304, 2000.

Jennerjahn, T. C., Ittekkot, V., Klöpper, S., Adi, S., Purwo Nugroho, S., Sudiana, N., Yusmal, A., Prihartanto, and Gaye-Haake, B.: Biogeochemistry of a tropical river affected by human activities in its catchment: Brantas River estuary and coastal waters of Madura Strait, Java, Indonesia, Estuar. Coast. Shelf S., 60, 503-514, https://doi.org/10.1016/j.ecss.2004.02.008, 2004.

Jennerjahn, T. C., Soman, K., Ittekkot, V., Nordhaus, I., Sooraj, S., Priya, R. S., and Lahajnar, N.: Effect of land use on the biogeochemistry of dissolved nutrients and suspended and sedimentary organic matter in the tropical Kallada River and Ashtamudi estuary, Kerala, India, Biogeochemistry, 90, 29-47, https://doi.org/10.1007/s10533-008-9228-1, 2008.

Jex, C. N., Pate, G. H., Blyth, A. J., Spencer, R. G. M., Hernes, P. J., Khan, S. J., and Baker, A.: Lignin biogeochemistry: from modern processes to Quaternary archives, Quarternary Sci. Rev., 87, 4659, https://doi.org/10.1016/j.quascirev.2013.12.028, 2014.

Kao, S. J. and Liu, K. K.: Particulate organic carbon export from a subtropical mountainous river (Lanyang Hsi) in Taiwan, Limnol. Oceanogr., 41, 1749-1757, 1996.

Keil, R. G., Tsamakis, E., Giddings, J. C., and Hedges, J. I.: Biochemical distributions (amino acids, neutral sugars, and lignin phenols) among size-classes of modern marine sediments from the Washington coast, Geochim. Cosmochim. Ac., 62, 13471364, 1998.

Killops, S. and Killops, V.: Introduction to Organic Geochemistry, 2nd Edn. (paperback), Geofluids, 5, 236-237, 2005.

Knorr, M., Frey, S. D., and Curtis, P. S.: Nitrogen additions and litter decomposition: A meta-analysis, Ecology, 86, 3252-3257, 2005.

Koh, L. P., Butler, R. A., and Bradshaw, C. J. A.: Conversion of Indonesia's peatlands, Front. Ecol. Environ., 7, 238-238, https://doi.org/10.1890/09.WB.013, 2009.

Kononen, M., Jauhiainen, J., Laiho, R., Spetz, P., Kusin, K., Limin, S., and Vasander, H.: Land use increases the recalcitrance of tropical peat, Wetl. Ecol. Manag., 24, 717-731, 2016.

Li, Z., Peterse, F., Wu, Y., Bao, H. Y., Eglinton, T. I., and Zhang, J.: Sources of organic matter in Changjiang (Yangtze River) bed sediments: preliminary insights from organic geochemical proxies, Org. Geochem., 85, 11-21, 2015.

Loh, P. S., Chen, C. T. A., Anshari, G. Z., Wang, J. T., Lou, J. Y., and Wang, S. L.: A comprehensive survey of lignin geochemistry in the sedimentary organic matter along the Kapuas River (West Kalimantan, Indonesia), J. Asian Earth Sci., 43, 118-129, 2012.

Lourençato, L. F., Bernardes, M. C., Buch, A. C., and Silva-Filho, E. V.: Lignin phenols in the paleoenviron- mental reconstruction of high mountain peatlands from Atlantic Rainforest, SE-Brazil, Catena, 172, 509-515, https://doi.org/10.1016/j.catena.2018.09.013, 2019.

Martin, P., Cherukuru, N., Tan, A. S. Y., Sanwlani, N., Mujahid, A., and Müller, M.: Distribution and cycling of terrigenous dissolved organic carbon in peatland-draining rivers and coastal waters of Sarawak, Borneo, Biogeosciences, 15, 6847-6865, https://doi.org/10.5194/bg-15-6847-2018, 2018.

Miettinen, J., Shi, C., and Liew, S. C.: Land cover distribution in the peatlands of Peninsular Malaysia, Sumatra and Borneo in 2015 with changes since 1990, Glob. Ecol. Conserv., 6, 67-78, https://doi.org/10.1016/j.gecco.2016.02.004, 2016.

Milliman, J. D. and Farnsworth, K. L.: Runoff, erosion, and delivery to the coastal ocean, River discharge to the coastal ocean: a global synthesis, Cambridge University Press, Cambridge, UK, 13-69, 2011.

Moore, S., Gauci, V., Evans, C. D., and Page, S. E.: Fluvial organic carbon losses from a Bornean blackwater river, Biogeosciences, 8, 901-909, https://doi.org/10.5194/bg-8-901-2011, 2011.

Moore, S., Evans, C. D., Page, S. E., Garnett, M. H., Jones, T. G., Freeman, C., Hooijer, A., Wiltshire, A. J., Limin, S. H., and Gauci, V.: Deep instability of deforested tropical peatlands revealed by fluvial organic carbon fluxes, Nature, 493, 660-663, https://doi.org/10.1038/nature11818, 2013.

Müller, D., Warneke, T., Rixen, T., Müller, M., Jamahari, S., Denis, N., Mujahid, A., and Notholt, J.: Lateral carbon fluxes and $\mathrm{CO}_{2}$ outgassing from a tropical peat-draining river, Biogeosciences, 12, 5967-5979, https://doi.org/10.5194/bg-12-5967-2015, 2015.

Opsahl, S. and Benner, R.: Early diagenesis of vascular plant tissues: lignin and cutin decomposition and biogeochemical implications, Geochim. Cosmochim. Ac., 59, 4889-4904, 1995.

Osono, T. and Takeda, H.: Organic chemical and nutrient dynamics in decomposing beech leaf litter in relation to fungal ingrowth and succession during 3-year decomposition processes in a cool temperate deciduous forest in Japan, Ecol. Res., 16, 649-670, 2001.

Otto, A. and Simpson, M. J.: Evaluation of $\mathrm{CuO}$ oxidation parameters for determining the source and stage of lignin degradation in soil, Biogeochemistry, 80, 121-142, 2006.

Page, S. E., Reiley, J. O., and Wust, R.: Lowland tropical peatland of Southeast Asia, in: Peatlands: Evolution and Records of Environmental and Climate Changes, edited by: Martini, I. P., Elsevier, 145-171, 2006.

Page, S. E., Morrison, R., Malins, C., Hooijer, A., Rieley, J. O., and Jauhiainen, J.: Review of peat surface greenhouse gas emissions from oil palm plantations in Southeast Asia, White paper, 76, 2011.

Pradhan, U. K., Shirodkar, P., and Sahu, B.: Physico-chemical characteristics of the coastal water off Devi estuary, Orissa and evaluation of its seasonal changes using chemometric techniques, Curr. Sci. India, 96, 1203-1209, 2009.

Pradhan, U. K., Wu, Y., Shirodkar, P. V., Zhang, J., and Zhang, G.: Sources and distribution of organic matter in thirty five tropical estuaries along the west coast of India-a preliminary assessment, Estuar. Coast. Shelf S., 151, 21-33, https://doi.org/10.1016/j.ecss.2014.09.010, 2014.

Prasad, M. B. K. and Ramanathan, A. L.: Organic matter characterization in a tropical estuarine-mangrove ecosystem of India: 
preliminary assessment by using stable isotopes and lignin phenols, Estuar. Coast. Shelf. S., 84, 617-624, 2009.

Rieley, J. O., Page, S. E., and Setiadi, B.: Distribution of peatlands in Indonesia, in: Global peat resource, edited by: Lappalainen, E., 169-178, International Peat Society, Jyskae, Finland, 1996.

Rieley, J. O., Wüst, R. A. J., Jauhiainen, J., Page, S. E., Wösten, J. H. M., Hooijer, A., Siegert, F., Limin, S. H., Vasander, H., and Stahlhut, M.: Tropical peatlands: carbon stores, carbon gas emissions and contribution to climate change processes, Peatlands and climate change, Inter. Peat Society, 148-181, 2008.

Spencer, R. G. M., Hernes, P. J., Ruf, R., Baker, A., Dyda, R. Y., Stubbins, A., and Six, J.: Temporal controls on dissolved organic matter and lignin biogeochemistry in a pristine tropical river, Democratic Republic of Congo, J. Geophys. Res.-Biogeo., 115, G03013, https://doi.org/10.1029/2009jg001180, 2010.

Staub, J. R. and Gastaldo, R. A.: Seasonal sediment transport and deposition in the Rajang River delta, Sarawak, East Malaysia, Sci. Sediment. Geol., 133, 249-264, 2000.

Sun, S., Schefuß, E., Mulitza, S., Chiessi, C. M., Sawakuchi, A. O., Zabel, M., Baker, P. A., Hefter, J., and Mollenhauer, G.: Origin and processing of terrestrial organic carbon in the Amazon system: lignin phenols in river, shelf, and fan sediments, Biogeosciences, 14, 2495-2512, https://doi.org/10.5194/bg-142495-2017, 2017.

Tareq, S. M., Tanaka, N., and Ohta, K.: Biomarker signature in tropical wetland: lignin phenol vegetation index (LPVI) and its implications for reconstructing the paleoenvironment, Sci. Total Environ., 324, 91-103, https://doi.org/10.1016/j.scitotenv.2003.10.020, 2004.

Tesi, T., Semiletov, I., Dudarev, O., Andersson, A., and Gustafsson, Ö.: Matrix association effects on hydrodynamic sorting and degradation of terrestrial organic matter during cross-shelf transport in the Laptev and East Siberian shelf seas, J. Geophys. Res.Biogeo., 121, 731-752, 2016.

Thevenot, M., Dignac, M. F., and Rumpel, C.: Fate of lignins in soils: A review, Soil Biol. Biochem., 42, 1200-1211, https://doi.org/10.1016/j.soilbio.2010.03.017, 2010.

Ward, N. D., Keil, R. G., Medeiros, P. M., Brito, D. C., Cunha, A. C., Dittmar, T., Yager, P. L., Krusche, A. V., and Richey, J. E.: Degradation of terrestrially derived macromolecules in the Amazon River, Nat. Geosci., 6, 530-533, https://doi.org/10.1038/ngeo1817, 2013.
Winterfeld, M., Goñi, M. A., Just, J., Hefter, J., and Mollenhauer, G.: Characterization of particulate organic matter in the Lena River delta and adjacent nearshore zone, NE Siberia - Part 2: Lignin-derived phenol compositions, Biogeosciences, 12, 22612283, https://doi.org/10.5194/bg-12-2261-2015, 2015.

Wit, F., Muller, D., Baum, A., Warneke, T., Pranowo, W. S., Muller, M., and Rixen, T.: The impact of disturbed peatlands on river outgassing in Southeast Asia, Nat. Commun, 6, 10155, https://doi.org/10.1038/ncomms10155, 2015.

Wu, Y., Bao, H., Yu, H., and Kattner, G.: Temporal variability of particulate organic carbon in the lower Changjiang (Yangtze River) in the post-Three Gorges Dam period: Links to anthropogenic and climate impacts, J. Geophys. Res.-Biogeo., 120, 2194-2211, https://doi.org/10.1016/j.orggeochem.2015.04.006, 2015.

Wu, Y., Eglinton, T. I., Zhang, J., and Montlucon, D. B.: Spatiotemporal variation of the quality, origin, and age of particulate organic matter transported by the Yangtze River (Changjiang), J. Geophys. Res.-Biogeo., 123, 2908-2921, https://doi.org/10.1029/2017JG004285, 2018.

Yu, H., Wu, Y., Zhang, J., Deng, B., and Zhu, Z.: Impact of extreme drought and the Three Gorges Dam on transport of particulate terrestrial organic carbon in the Changjiang (Yangtze) River, J. Geophys. Res.-Earth, 116, F04029, https://doi.org/10.1029/2011jf002012, 2011.

Zaccone, C., Said-Pullicino, D., Gigliotti, G., and Miano, T. M.: Diagenetic trends in the phenolic constituents of Sphagnumdominated peat and its corresponding humic acid fraction, Org. Geochem., 39, 830-838, 2008.

Zhu, S., Dai, G., Ma, T., Chen, L., Chen, D., Lu, X., Wang, X., Zhu, J., Zhang, Y., Bai, Y., Han, X., He, J., and Feng, X. J.: Distribution of lignin phenols in comparison with plant-derived 65 lipids in the alpine versus temperate grasslands soils, Plant Soil, 439, 325-338, 2019. 